\title{
Kyoto, CONSTITUTIONAL LAW AND AlBERTA's Proposals
}

\author{
Nigel D. BANKES AND AI.ASTAIR R. LUCAS*
}

This article examines Alberla's Bill 37, a provincial plan to reduce greenhouse gases and climate change. and explores the constitutionality of such legislation. Its main focus revolves around a constitutional analysis of Alberta's proposed legislation and its potential incompatibility with federal initiatives used to meet the Government of Canada's commitments under the Kyoto Protocol. In this discussion, the authors conclude that Bill 37 would likely be constitutionally valid under the provincial subject matter of property and civil rights, and possibly local undertakings and ownership of provincial public lands. However, the anthors dismiss the argument that Alberia's legal position over any federal imiliative would be bolstered by the Crown's ounership of provincial resources.

The article then looks to the federal government's Kyoto commitmen's and analyzes the constitutionality of possible federal initiatives under the federal subject matters of taxation, criminal law. trade and commerce and POGG. With both the Alberta and federal plans analyzed, the authors then discuss the potential incompatibility of the plans through three possible scenarios. The article concludes with a brief discussion of the other cooperative measures, such as equivalency agreements and incorporation by reference, which the federal and provincial governments may use to combat the issue of climate change.
Cet article examine le projet de lof 37 de l'Alberia. projef provincial visani à réduire les gaz à effel de serre ef le changement climatique ud déterminer si une telle législation est bien constitutionnelle ou non. le point central tourne aulour de lanalyse constitutionnelle du projet de loi de l'Alberia et de son éventuelle incompatibilité avec les initiatives fédérales utilisées pour respecter les engagements que le Gouvernement du Canada a pris en verfu du Procole de Kyoto. Dans cette discussion, les auteurs concluent que le projet de loi 37 serait sans doute constitutionnel sur le plan des droits de propriets ef des droils civils provinciaux, ef peut-itre aussi sur te plan des engagements locatur et de proprieté des terres publiques de lo province. Toutefois, les auleurs rejettent l'argument que la position juridique de l'Alberta à l'égard d'une initiative fédérale serail soufenue par le fail que les ressources de la province appartiennent à la Couronne.

Larticle examine ensuite les engagements du gouvernement fédiral à l'égard du l'rotocole de Kyoto et analyse l'aspect constiturionnel d'éventuelles initiatives federates relativement a la fiscalite. an droit pinal. à lichange et au commerce et lex dispositions concernam la pax el l'ordre ainsi que le bon gouvernement. Après avoir analysé les projets de LAlberfa et du gouvemement fedsral, les aufeurs discutent l'incompatibilité éventuelle de projets au moyen de trois scénarios possibles. L'article se termine par une brève discussion sur d'autres mojens coopératifs, tels que les accords d'équivalence et I'incorporation par référence que les gouvernements federal ef provincianx pewvent untiser pour lutier contre la question du changement climatique.

\section{TABLE OF CONTENTS}

1. THE PURPOSE AND SCOPE OF THE ARTICI.F $\ldots \ldots \ldots \ldots \ldots \ldots \ldots \ldots 6$

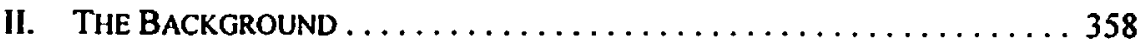

A. The Problem of Global Clumate Change .......... 358

B. GREENHOUSE GAS EmISSIONS AND CANADA'S "KyOTO GAP" . . . 359

C. The Kyoto Obligations and Mechanisms $\ldots \ldots \ldots \ldots \ldots 360$

D. The Legal and CONSTItUTIONAL EFFECT

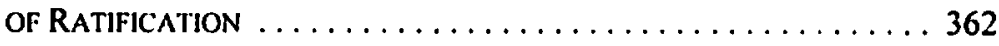




\section{E. COMPARISONS BETWEIEN KYOTO IMPLEMENTATION}

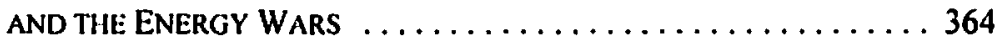

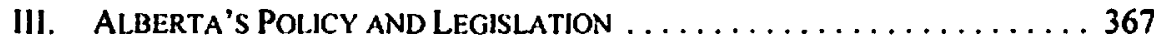

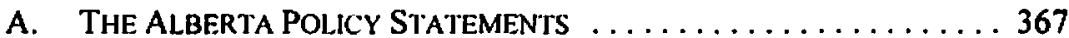

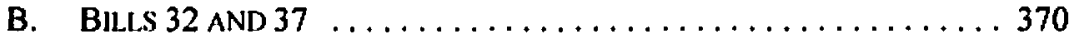

C. The Constitutional Framework:

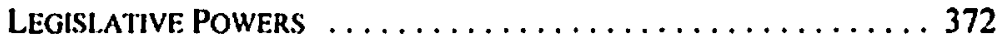

D. Relevant Provincial. Powers $\ldots \ldots \ldots \ldots \ldots \ldots \ldots \ldots \ldots \ldots \ldots \ldots \ldots$

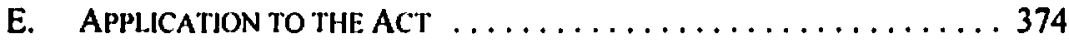

F. ALLOCATION ........................... 376

G. EXCURSUS: THE ROLE OF PROVINCIAI.

Property RightS . . . . . . . . . . . . . . . . . . . . . . 377

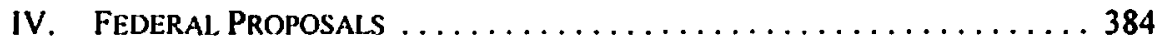

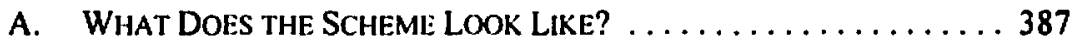

B. A PRLLIMINARY NOTE ON FEDERAL. JURISIJICTION:

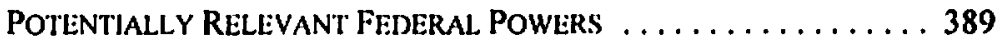

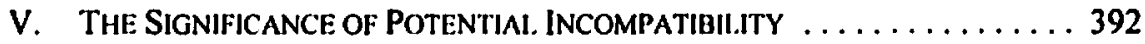

VI. POTENTIAL EQUIVAlENCY OR

INCORPORATION BY REFERENCE: $\ldots \ldots \ldots \ldots \ldots \ldots \ldots \ldots \ldots \ldots \ldots$

VII. Conclusions ................................. 397

\section{The Purpose and SCOPE of the ARTicle.}

This article has two main objectives. The first objective is to describe Bill 37, Alberta's Climale Change and Emissions Management Act' and then to assess the constitutional underpinnings of that bill. The second objective is to consider the extent to which Alberta's Bill lends itself to a federal-provincial cooperative approach to deal with the problem of climate change and specifically the implementation of Canada's commitments under the Kyoto Protocol to the United Nations Framework Convention on Climate Change ${ }^{2}$ (hereafter respectively, the Kyoto Protocol and UNFCCC ${ }^{3}$ ). Canada ratified the Kyoto Protocol on 17 December 2002 and thereby assumed the obligation to achieve a 6 percent reduction in greenhouse gas (GHG) emissions below 1990 levels within the 2008-2012 first commitment period.

3d Sess., 25th L.eg., Alberta, 2003 (assented to 4 December 2003, not yet proclaimed into force as of publication), also found in R.S.A. 2000, c. 16.7 [Bill 37]. The Bill replaces an earlier initiative, Bill 32, Climate Change and Emissions Management Act, 2d Stss., 25th Leg., Alberta, 2003, which was given first reading 19 November 2002 and second reading 26 November 2002.

: 11 December 1997. U.N. Doc. FCCC/CP/1997/L.7/Ad. I. (1997) 37 1.L.M. 22 [Kyoto Protocol]. Al the time of writing the Kyoto Prolocol was not yet in force. It will not enter into foree until it has been ratified by at least 55 incorporating parties who account for at least 55 percent of 1990 carbon dioxide $\left(\mathrm{CO}_{\text {: }}\right.$ ) emissions of Annex I Parties to the UNFCC'C( ant. 25). The text of the $\mathrm{K}^{\prime}$ yolo Protocol and stalus of ratifications is available online: $U N F C C C<$ unfece int/ . Al time of publication there were 122 ratifications representing $\mathbf{4 4 . 2}$ pereent of emissions. Given the decision of the United States not to ratify, it is widely accepted that the Kyoto Profocol will not enter into force unless and until the Russian Federation ratifies.

United Nation Framework Comention on Climate Change, 9 May 1992, 1771 U.N.T.S. 107 [LNFCCO]. 
The second objective requires us to consider the extent to which the Alberta proposals are consistent with the federal proposals, which are articulated in Climate Change Plan for Canada $a^{4}$ released on 21 November 2002 and designed to inform Canada's decision to ratify the Kyoto Protocol. It also requires that we consider what might be the legal implications if the Alberta and federal schemes prove to be incompatible. There are some limits to how far we can pursue this analysis at the present time. The federal government has yet to indicate with any precision what legislative measures it plans to put in place to facilitate the implementation of Kyoto commitments. The federal Climate Change Plan envisages that Kyoto commitments will be met principally through a combination of a variety of incentive programs and a cap and trade program for large industrial emitters." The details of the various schemes, and especially the architecture of the cap and trade system, have yet to be spelled out. ${ }^{6}$ For this reason the article does not consider in any detail the constitutional validity of the federal proposals. However, we do provide some preliminary assessments of the proposals as currently understood and some preliminary assessment of the compatibility of the federal and provincial programs.

The article proceeds as follows. Part II provides necessary introductory material including a brief outline of the problem of global climate change and the main Kyoto obligations and mechanisms. Part II.D provides a brief description of the rules of Canadian constitutional law pertaining to the signature, ratification and implementation of international agreements such as the Kyoto Protocol. Part II.E serves to introduce the current constitutional conflict over Kyoto implementation by comparing the current debate with the debate of the 1970s and early 1980s over energy pricing and the sharing of economic rents fowing from increased world oil prices.

Part III turns to a description of Bill 37 and the Alberta scheme. It also provides a framework for examining the constitutional validity of provincial laws and then applies that framework to Bill 37. Part III.G concludes with a lengthy excursus that assesses provincial government claims to the effect that the provincial government's legal position in any dispute with Ottawa over Kyoto implementation is significantly bolstered by the resource ownership position of the Crown. We conclude that there is little support for such an argument. Part IV

- Canada, Climate Change Planfor Canada (Otawa: Govemment of Canada, 2002), online: (jovernment of Canada, Climate Change <mww. climatechange.gc.ca/plan_for_Canada/plan/pdfffullversion.pdi> [Plan].

- Under a cap and trade program, or a tradeable emission permit scheme. government establishes a cap on total emissions for large industrial emitters and creates a number of permits representing units of emissions equal to that cap. Emitters must have a pernit entitlement to cover all of their emissions. Government determines the initial allocation of the permits and their characteristics (duration, eic.), but after that permits are freely tradeable.

" That said, considerable background work has been undertaken on this topic. Sec in particular, Canada, Tradeable Permits Working Group (TPWG). Using Tradeable Eimissions Permits to Ile/p Achieve Domestic Greenhouse Gas Objectives, Options Report. (Ottawa: Tradeable Permils Working Group of the National Climate Change Process, 2000), online: Canada's National Climate Change Process <www.ncep.ca/html/tahles/pdi/options/TPWG_en_hw.pdf> [TPW(i, Optioms Reporl|. Also set discussion papers, particularly "Discussion Paper on the Allocation of Greenhouse Gas Emission Targets to L.arge Industrial Emitters," online: Natural Resources Canada < www.nrcan-rncan.ge.ca/fegggcf/English/discl -en.pdß: "Timing/Frequency of Trut-up and Permit Distribution," online: Natural Resources Canada <www.nrcin-rncan.gc.ca/lfeg-ggef/English/timing-en.pdf>; and "Permit Definition," online: Natural Resources Canada <www.nrean.gc.ca/tieg-ggef/Linglish/permit-definition-en.pdl>. 
offers a brief outline of the federal plan. This is not to assess in any detail the validity of any federal legislation designed to implement the federal scheme (it is premature to engage in that analysis), but largely to reach some preliminary assessment of the compatibility of the provincial scheme with current federal proposals.

\section{THE BACKGROUND}

\section{A. The Problem of Global Climate Change}

There is a strong consensus amongst scientists that global climate change is already occurring and that human (anthropogenic) activity is contributing to it. The reports of the Intergovernmental Panel on Climate Change (IPCC) offer an effective summary of that consensus. ${ }^{7}$ The third assessment report of IPCC was completed in 2001. The fourth assessment report is anticipated in 2007. The basic elements of the assessment are well known and may be summarized here as follows: ${ }^{8}$

Most of the observed global warming over the last 50 years is likely due to increases in greenhouse gas (GHG) concentrations. These concentrations have continued to increase as a result of human activities.

The principal GHG gases are $\mathrm{CO}_{2}$ (about three quarters related to fossil fuel burning, the rest predominantly due to land use change especially deforestation), methane, nitrous oxide, and halocarbons (many of which are regulated by the Montreal Protocol).

The ocean and land together absorb about 50 percent of anthropogenic $\mathrm{CO}_{2}$ emissions.

The globally averaged surface temperature is projected to increase 1.4 to $5.8^{\circ} \mathrm{C}$ between 1990 and 2100 .

Northern nations will be more affected than countries closer to the equator.

There will likely be more frequent occurrences of extreme weather and climate events including continental drying. There will be more intense rainfall as well as increases in tropical cyclones wind and precipitation intensities.

- The global mean sea level is projected to rise by $0.09-0.88$ metres between 1990 and 2100.

3 The Intergovernmental Pancl on Climate Change (IPCC) has three working groups. WG I deals with the science issues, WG II considers impacls, adaptation and vulnerability, and WG III considers mitigation. IPCC reports are available online: IPCC $<w w w . i p c e . c h />$.

Ibid.

Montreal Protocol on Substances that Deplete the Ozone Layer, 16 September 1987, 16 I.L.M. 1541, online: United Nations Envitonment Program <www.unep.org/ozone/Montreal-Protocol/MontrealProtocol2000.shtml> 
Anthropogenic climate change will persist for many centuries.

There remain significant uncertainties in these assessments especially in relation to the timing and rate of future changes.

The federal government's Climate Change Plan complements this assessment and argues that Canadians are already feeling the effect of global warming through "increasing number and intensity of heat waves and related health problems; declining water levels in the Great Lakes; changes in fish migration and melting of the polar ice cap, insect infestations in British Columbia's forests; hotter summers and higher levels of smog in major urban centres; and more extreme weather events such as droughts on the Prairies, ice storms in eastern Canada, flooding in Manitoba and Quebec."10

From a constitutional perspective, it is important to emphasize that the problem is a global problem; GHGs have the same impact on the atmosphere regardless of where they are emitted and reductions in GHG emissions redound to the benefit of all.

\section{B. Greenhouse Gas Emissions and Canada's "Kyoto Gap"}

In global terms, Canadian GHG emissions are not large, amounting to 2.2 percent of global emissions." However, on a per capita basis, Canada ranks ninth among nations. ${ }^{12}$ Seventy-three percent of total Canadian emissions were produced by fossil fuel combustion, and, overall, the energy sector was responsible for 80.3 percent of emissions. ${ }^{13}$ During the period 1990-1999, the energy sector contributed 96.6 percent of the $91.4 \mathrm{MT}$ increase in total GHG emissions. ${ }^{14}$ However, over the same period, total Canadian GHG emissions per unit of gross domestic product (GDP) decreased, largely as a result of energy efficiency gains and fuel switching away from fossil fuels. ${ }^{15}$

Projecting emissions to 2020 reveals what has been characterized the "Kyoto Gap"; that is, the difference between projected emissions and Canada's 6 percent reduction below 1990 levels under the Kyoto Protocol. Initially, in Canada's second National Report the gap was approximately 21 percent. ${ }^{16}$ Updated projections suggest higher emissions and a larger gap in 2010. However, by taking into account Canada's 2000 Action Plan with its planned annual emissions reduction of $65 \mathrm{MT}$, the projected gap is reduced to 19 percent. ${ }^{17}$

Supra nole 4 at $\mathrm{I}$.

Canada, Third National Report on Climate Change (Otawa: Government of Canada, 2001) at 23. online: Government of Canada. Climate change <mmw.climatechange.ge.ca/english/publications/ 3nr/3NR-Published-Version-I:N.pdP [Third National Report].

lbid.

lbid. at 30.

lbid. at 28.

lbid. at 26.

Ibid. at 83.

Ibid. 
Alberta produced 31 percent of the 2001 national emissions total, ${ }^{18}$ and this is projected to increase by 40 percent by the year $2010 .{ }^{19}$ Significantly, Alberta's petroleum and primarily coal fired electricity generation accounts for 51 percent of its total, while in the rest of Canada, these sources produce only 21 percent of emissions. ${ }^{20}$ For the mainly Alberta-based fossil fuel industry, emissions are expected to increase by 64 percent between 1990 and 2010 . The Third National Report states that: "This increase largely reflects the growth in oil sands production and higher natural gas exports to the United States that are anticipated to occur during this period."21

\section{The KYOTO OBLIGATIONS AND MECHANISMS}

Central to the Kyoto Protocol is the art. 3 commitment of so-called Annex I parties (of $U N F C C C$ ) to ensure that "their aggregate anthropogenic carbon dioxide equivalent emissions" of GHGs "do not exceed their assigned amounts ... inscribed in Annex B."22 Annex B to the Kyoto Protocol contains the specific commitments of these parties for quantified emission limitations or reductions for the first commitment period. Canada's commitment, as stated in the introduction, is to limit its emissions to 94 percent of 1990 levels (the base year). The first commitment period runs from 2008-2012. The Climate Change Plan interprets this as requiring a reduction of 240 MT (megatonnes) from "projected 'business-as-usual' emissions level in 2010."23 The obligation described here is an obligation of result. That is, the Kyoto Protocol does not prescribe how parties are to achieve their commitments and does not prescribe the use of particular instrument choices. ${ }^{24}$

In determining whether a party has met its commitments, account will be taken of net changes in emissions from sources and removals by sinks including human induced land use changes and forestry activities. ${ }^{25} \mathrm{~A}$ party may meet its art. 3 commitments by a combination

13 Environment Canada, Greenhouse Gas Division, Canada 's Greenhouse Gas Emission Inventory 19902001 (Ottawa: Environment Canada, 2003) at 9, online: Environment Canada < 1990_01_report/1990_01_report_e.pdP. Approximate percentage based on table reproduced at 9. National Climate Change Process, Analysis and Modelling Group, Cancda's Emissions Outook: An Update, (Ottawa: Government of Canada, 1999) at 51, online: Natural Resources Canada <www.nrcan. gc.ca/es/ceo/outlook.pdis.

3" J. Donner, "Alberta Environment Strategic Direclions," Alberta Environment, 5 Ficbruary 2002.

"Third National Report, supra trolt 11 at 85.

$2 \quad$ Supra note 2, an. 3.1. The language of Annex I and Annex $B$ is apt to confuse. For charity it is best to refer to an Annex I party to the UNFCC'C as having made a conmitment under Annex $B$ of the Protocol (i.e. Annex 1 refers to partics and Annex B to commitments). The Annex I list includes eastern European countries, the so-called countries with cconomies in transition (EITs).

21 Supra note 4 at II.

24 Article 2 of the Protocol contains a list of possible polices and measures that parties may adopt. For discussions of the general problems of instrument choice in the context of Kyoto see Jonathan Baert Wiener, "Global Environmental Regulation: Instrument Choice in Legal Context" (1999) 108 Yale L.J. 677. Note that while Kyoro imposes an obligation of result, it does provide an incentive to parties to achieve their commitments through a cap and trade sclieme. This is because, as detailed below, Kyoto permits international trading thereby allowing a domestic trading scheme to mesh with an international scheme. It would be diflicult for a domestic carbon tax to mesh with an international trading system.

$\because \quad$ The bare provisions of the $X^{\prime}$ yoto Prolocol have been claborated in a series of decisions adopted by the Conference of the Parties (CoP) to the UNFCCC on its Seventh Session and collectively known as the Marrakesh Accords, 29 October to 10 November 2001, U.N. Doc. FCCC/CP/2001/13/Add.1, U.N. Doc. FCCC/CP/2001/13/Add.2, U.N. Doc. FCCC/CP/2001/Add.3, U.N. Doc. FCCC/CP/2001/Add.4. All of these decisions will need to be reaffirmed by the first Meeting of the Parties to the Kyotc Protocol 
of reducing GHG emissions and GHG removals that occur through enhancing approved carbon sinks ${ }^{26}$ so as to produce measured, verifiable changes in carbon stocks. ${ }^{27}$

The Kyoto Protocol also contemplates that an Annex I party may meet its Annex B commitments by availing itself of one or more market-based mechanisms. The Kyoto Protocol describes three such mechanisms: joint implementation (JI), trading and the clean development mechanism (CDM). ${ }^{28}$

Article 6 provides a bare outline of $\mathrm{JI}^{29}$ The article authorizes an Annex I party to receive credits against its emissions limits in return for supporting projects in another Annex I party (for example, an eastern European country - a country with an economy in transition (EIT)) that reduces emissions or enhances sinks. An example might be an approved Canadian firm applying Canadian technology to improve the seal and compression pumps on a pipeline project in an EIT country, thereby generating credits by reducing fugitive emissions. ${ }^{30}$

Article 17 of the Kyolo Prolocol provides the barest outline or authorization for a trading mechanism and indicates that Annex $B$ parties may engage in trading in order to fulfil art. 3 commitments, with the details of the trading scheme to be worked out by the Conference of the Parties. ${ }^{31}$ Under this scheme Canada, or approved Canadian firms, would be able to buy permits on an open market or through an international broker. The Climate Change Plan indicates that Canada will consider entering this market to purchase a minimum of $10 \mathrm{MT}$, with a preference to be accorded to CDM/JI projects. ${ }^{32}$

once the Kyoto Protocol enters into force.

:" 'A 'sink' is any process that removes $\mathrm{CO}_{2}$ from the atmosphere and stores it. Forests and agricultural soils can act as carbon sinks. Plants absorb $\mathrm{CO}_{2}$ from the atmosphere through the process of photosynthesis. The $\mathrm{CO}_{2}$ is stored in the plant tissue. Agricultural soils can act as a sink when $\mathrm{CO}_{2}$ removed from the atmosphere by crops is slored in the roots. When the plant dies, some proportion of the plant tissue remains in the soil and is transformed into soil organic matter" (Climate Change Plan. supra nole 4 at (2).

:Article 3.3 refers to approved carbon sinks as being limited 10 alforestation, reforestation and deforestation but ant. 3.4 contemplates that additional human induced activities may be added to this list (Kjoto Protocol, supra nole 2). See Marrakesh Accords, supra note 25, Decision II/CP.7.

There is, in fact, un additional meclunism, the so-called "bubble" mechanism described in art. 4 (Kyoro Profocol, ibid.). This mechanism, designed principilly to deal with the F:I, contemplates that two or more Annex I parties iniglt agree to pool their commitments and meet their obligations jointly. Parties intending to avail themselves of this option must indicale so when depesiting their instruments of ratification. EU member countries have availed themselves of this oplion; Canada has not. For the EU ratificalion statement on Jl see "The European Community and its Member Stales will fulfil their respective commitments under Article 3. paragraph 1 , of the Protocol jointly in accordance with the provisions of Article 4" in Kyoto Protocol on Ratification," online: UNFCCC <unfece. intresource/ kpstats.pdi $\$$. There was some speculation that Canada might pursue a bubble mechanism with Russia. Nothing came of this.

:2 For the details see Marrakesh Accords, stupra note 25, 1)ecision 15/(P.7.

"1" Climate Change Plam, supra nole 4 al 43.

1 Sec Marrakesh Accords, sipra note 25. Decision $18 / \mathrm{CP} 7$.

1: Supra note 4 at 44 . The Plan also indicalcs that Canada will only enter the general market to purchase credits from EITs if the EIT will commit to investing the proceeds of the sale in projects and activities that contribute to emissions reductions. 
The third mechanism of the CDM is described in somewhat more detail than the previous mechanisms in art. 12 of the Kyoto Protocol. ${ }^{33} \mathrm{CDM}$ is similar to $\mathrm{JI}$ but contemplates that Annex I parties may meet their Annex B commitments by funding projects in non-Annex I countries that contribute to sustainable development and the overall objectives of the $U N F C C C$, and result in "[r]eal, measurable, and long-term benefits related to the mitigation of climate change." ${ }^{34}$ An example of a CDM project might be Canada or an approved Canadian firm funding a project to capture methane gas from a landfill site and using that gas to provide generating capacity for a local urban area, thereby meeting the twin objectives of emission reductions and improvement in the quality of life of urban residents. ${ }^{35}$

In addition to the key obligation of reducing emissions, the parties to the Kyoto Protocol also assume important procedural obligations dealing with reporting and monitoring in order to provide the basis for a robust compliance scheme. ${ }^{30}$

In conclusion, the Kyoto Protocol imposes an obligation of result on Annex I countries to meet their Annex B commitments. It does not stipulate how that obligation should be met. The Kyoro Protocol offers some market-based options to assist parties in meeting their obligations but it does not require their adoption. Neither is this list exhaustive of the economic approaches that might be taken to the problem of instrument choice. ${ }^{37}$ In the case of each of the market-based options, the Kyoto Protocol envisaged that the Conference of the Parties to the UNFCCC, meeting as the Meeting of the Parties to the Kyoto Protocol, (CoPIMoP) would further elaborate these optional mechanisms. This work has now been largely undertaken, although the relevant decisions will only become fully effective when the Kyoto Protocol enters into force.

Having outlined the basic problem of global warming as well as some of the key provisions of the Kyoto Prolocol that must inform the Canadian response, we can now turn to look at the legal and constitutional effect of Canada's ratification of the Kyoto Protocol and then look in turn at Alberta's proposals for responding to the problem of climate change and the federal government's implementation plans.

\section{The Legal and Constrtutional. EfFect of Ratification}

It is trite law in Canada that treaties are not self implementing and thus the Kyolo Protocol does not become part of domestic law by the act of ratification; it only becomes part of domestic law (to the extent that it requires a change in domestic law) when incorporated by

And further detailed in the Marrakesh Accords, supra nole 25, Decision 17/CP.7.

Kyoto Protocol, supra note 2, art. 12.5(b).

Climate Change Plan, supra note 4 at 43 .

See Jutta Brumete, "A lime Balance: Facilitation and Enforcennent in the Design of a Compliance Regime for the Kyoto Profocof" (2000) I3 Tul. Envtl. L.J. 223. For details of the compliance schene. sec Marrakesh Accords, supra nole 25, Decision 24/CP.7.

As already noted at art. 2.1 (a) provides a much more extensive menu of policy instruments. Clause (v), for example, refers to a range of market instruments including taxes, incentives and elimination of perverse subsidies. 
the relevant jurisdictional authority (such as Parliament or provincial legislatures and their delegates). ${ }^{38}$

It is equally trite law in Canada that ratification of an international instrument does not by itself extend the legislative powers of Parliament. The leading case is still the Privy Council's decision in the Labour Conventions case ${ }^{39}$ where the Committee, after distinguishing earlier authorities, ${ }^{40}$ took the view that

lior the purposes of ss. 91 and $92 \ldots$ there is no such thing as treaty legislation as such. The distribution is based on classes of subjects; and as a treaty deals wilh a particular class of subjecls so will the legislative power of performing it be ascertained."

The rationale offered for this position was that to hold otherwise would "undermine the constitutional safeguards of Provincial constitutional autonomy." 42 Thus, while the capacity of the federal executive had expanded as Canada attained international status, there was no corresponding change in the legislative power to implement these obligations. The Committee offered the solution of cooperative arrangements to the problem engendered. ${ }^{43}$

in Ruth Sullivan, Dreidger on the Construction of Stantes, 3d ed., (Markham: Butterworths, 1994) at 396. Sullivan properly adds that an agreement might be implemented by the prerogative to the extent that a residual prerogative power is engaged. An agreement also becomes part of the context for interpretation of domestic statutes: Baker v. Canada (Minisier of Citizenship and immigration), [1999] 2 S.C.R. 817; /14957 Canada Like (Spraytech, Societe d'arrosage) v. Hudson (Town of, [200]] 2 S.C.R. 241. For recent and more comprehensive surveys of the implementation of Canadian treaty obligations in domestice Jaw sec: Gibran Van Err, "Using Treaties in Canadian Courts" (2000) 38 Can. Y.B. Int'l Law 3 and Jutta Brunee \& Stephen J. Toope. "A llesitant Embrace: The Application of International Law by Canadian Court" (2002) 40 Can Y.B. Int'I Law 3.

" Canada (A.G.) v. Ontario (A.G.). [1937]A.C. 326 (P.C.)|Labour Conventions]. In that case Parliament purported to pass laws dealing with weekly rest, hours of work and ininimum wage, all in order lo give effect to three Intemational labour Conventions (ILO) Conventions that Canada had rattified.

4) The Committee, ibid. at 350-5I, distinguished the Aeronautics Case. [1932] A.C. 54 (P.C.), on the grounds that in that case the relevant treaty engaged s. 132 of the Constirution $1 \mathrm{ct}$. 1867 (dealing with Imperial treaties) and the Radio Case, [1932] A.C. 304 (P.C.), on the grounds that the matter of the treaty in that case did not fall within any of the enumerated heads of s. 91 or $\mathrm{s} .92$ and was therefore a new matter that properly fell within the residual opening words of s. 91 . Supra note 39 at 351 .

Ibid. at 352.

The Committee rejected the federal government's alternative arguments based on $\mathrm{s} .132$ and on the peace, order and good government power. The latter argument was put on a very brond basis: "thal where Canada has properly incurred an international obligation with respect to any matler whatsoever. that within whatever classes in ss. 91 and 92 it may be described as coming under olher circumstances. once the matter has assumed the aspect of an international bargain it is no innger to be treated as belonging ro any' one of the enumeraled classes" (ibid at 330 [emphasis added]). P'ut that way it is hardly surprising that the Committec rejected it as "a ven far-reaching doctrine" (ohod at 330) but much of the Committec's reasoning appears (ibid. at 353 ) to be based on the fact that the lederal government could not bring the proposed legislation within the ambit of an emergency: clearly there was no such emergency. 
Although there are Supreme Court dicta suggesting that it may be appropriate to reconsider Labour Conventions, ${ }^{44}$ and others have questioned its authority, ${ }^{45}$ it is still good law.

Although there are obvious parallels between Labour Conventions and Kyoto implementation, there are limits to the analogy. The particular ILO conventions at issue in that decision dealing with hours of work, weekly rest and minimum wage, did not impose an obligation of result but prescribed obligations that did not admit of a broad range of options for their fulfillment. Accordingly, while the federal government could implement the ILO convention with respect to its own employees and other employees who fell directly under federal jurisdiction, it was powerless to implement the UNFCCC with respect to the bulk of employees whose employment relationship would be the subject of provincial jurisdiction over property and civil rights. ${ }^{46}$

\section{E. COMPARISONS BETWEEN KYOTO IMPLEMENTATION AND THE ENERGY WARS}

Implementation of the Kyoto Protocol has the potential to create serious conflict between the carbon-based energy producing provinces and the federal government. We can see this by taking as an example the use of a cap and trade system to curb carbon emissions. The result of such a system is to create a new form of property right, an emissions permit, which will be a valuable asset and potentially entail significant wealth transfers depending upon the manner in which such a scheme is implemented:

The total value of permits represents a transfer from consumers (who pay higher prices including the cosis of permits) and/or producers (who may receive lower prices net of any permit costs). The transfer is initially 10 the government if the permits are auctioned, and subsequently to whomever benefils from any consequent tax reductions. If the permits are provided gratis, the transfer is initially to whomever receives them (though those people/firms are also likely to be subject to costs associated with the imposition of a permits requirement). ${ }^{47}$

The initial distribution of permits will therefore inevitably be contested. And even if the bulk of the permits are initially distributed gratis, thereby protecting the interests of

See Re Reference Ownership of Offshore Mineral Righis (B.C.). [1967] S.C.R. 792 at $815-17$ (no explicit discussion of the malter); MacDonald v. Vapour Canada L.sd., [1977] 2 S.C.R. 134 at 167-72; Schmeider v. The Queen. |1982] 2 S.C.R. I12 at 134-35 (in each of these latter cases the cour suggests that if Parliament wished to rcly upon the so-called treaty power then the intention to do so must be manifested on the face of the implementing legislation and not be left to inference).

1" See Peter W. Hogg, Constitustional Law of Canada, 4th ed. (Scarborough: Carswell, 1997) at 300-304. who strongly criticizes the Privy Council's reasoning in the Labour Conventions case; and Doug Thomson, "Constitutional Jurisdiction Over the Kyoto Protocol" (Paper prepared for Canadian Institute Conference, What's New in Environmental Law and Regulation in Ontario, May 2002). For a comprehensive review and spirited defence of Labour Conventions see Van Ert. supra note 38 al 63-79. Note as well that an. 405(9) of the Treaty of Versailles. which dealt with the subject of ILO Conventions, contained a version of a federal clause that allowed a contracting party that was a federal stale to indicale that it accepled a particular convention as a recommendation rather than as a binding convention. The article is reproduced in the case, Labour Conventions, supra note 39 at 345 . As is typical of modern multilateral environmental agreements, the $K$ yoto Protocol does not contain a federal clause.

1) TPWG, Options Report, supra note 6 at 5. On cap and trade systems as hybrid property sec Carol M. Rose, "Expanding the Choices for the Global Commons: Comparing Newfangled Tradable Allowance Schemes to Old-Fashioned Common Property Regimes" (1999) 10 Duke Envtl. L. \& Pol'y F. 45. 
incumbents, there will be ongoing questions as to the extent to which incumbents should continue to be protected. As the permits acquire value, emissions will become part of the price for all users downstream of the permit thereby curbing demand, which will affect those who supply labour and other inputs.

The contest over the allocation of the burden of achieving GHG reductions invites comparisons with the so-called "energy wars" of the 1970s and 1980s between the western provinces and the federal government. But by comparison with the problem of climate change, the issue underlying the energy wars was the relatively simple one of sharing the available economic rents between the federal government and the provincial governments, and between producing interests and consuming interests. The debate became particularly bitter because the amount of rent available from conventional oil and gas development had soared along with soaring world prices.

While the legal debate during the energy wars revolved necessarily around whether certain economic rent collection techniques were available to particular governments (given that the two governments each had the capacity to tax to death the goose that laid the golden egg ${ }^{48}$ ), the real issue was a political or ethical one - how should the revenues be shared? ${ }^{49}$ This question is a faimess question and there is no legal or economic answer. However, it is a question that the parties had to solve if the industry were to survive. No party could resolve the issue unilaterally since a crown royalty designed to collect the entire economic rent was obviously constitutional, just as a federal tax on energy production would be constitutional provided that it stayed away from taxing provincially owned property. Thus the question had to be solved by agreement. There was therefore a very strong incentive for the parties to keep negotiating. There was another aspect to the fairness debate at the time that deserves mention. It is clear that the National Energy Program targeted the oil and gas sector. Yet one of the consequences of world price increases for oil and gas was also an increase in the rents available from the generation of electricity. ${ }^{50}$ Some of Alberta's concerns were that its oil and gas industry was being treated unfairly by comparison to the hydro-electric sector of other provinces.

The climate change debate is similarly a debate about faimess or equity. But the fairness debate is not about how to share the larger pie of increasing economic rents. Rather, it is a debate about how the costs (burden) of meeting the Kyoro targets should be shared. While there was some uncertainty associated with the amount of rent available for sharing during the energy wars (and it turned out to be far less than originally predicted when world oil

W.R. Lederman, "The Constitution: A Basis for Bargaining" in Anthony Scott, ed., Natural Resource Revenues: A Test of Federalism. (Vancouver: University of British Columbia Press, 1976) 52 at 57. "There is no constitutional prohibition against killing geese that lay golden eggs." The term tent or cconomic rent (as used in this section) refers not to the rent payable by a tenant to a landlord but instead to the difference between the market value of a resource and all of the costs (full-cycle costs) including a reasonable return on invested capital. Used in this sense a rent represents a true surplus that can be appropriated by government without creating a disincentive to invest in the oil and gas sector. Sec Michael Crommelin, "Government Management of Oil and Gas in Alberta" (1975) 13 Alta. L. Rev. 146 , especially at 148 .

" Anthony Scott, "Who Should Get Natural Resources Revenues?" in Scolt, sbid. at I.

3. Economic Council of Canada, Connections: An Energy Strategy for the Future, (Ottawa: Minister of Supply and Services, (985) at 90-91. 
prices did not continue to rise as anticipated), there is much greater uncertainty associated with the costs of dealing with climate change as well as the incidence of the costs associated with particular instrument choices."

The tools available to the key protagonists during the energy wars are well known. The federal government introduced a range of taxing measures and, as well, sought to prescribe the price of oil and natural gas in interprovincial trade. ${ }^{52}$ Both techniques served to appropriate available rent. The province responded by questioning the validity of part of the federal taxation legislation by way of a reference to the Alberta Court of Appeal ${ }^{53}$ and secured its own share of rents, primarily through the variable royalty regime to which all Crown agreements were subject. ${ }^{54}$ It ultimately went on the offensive by ordering Crown lessees to shut in production. ${ }^{55}$ One of the observations of this paper is that while the federal government has at least as large a toolkit of possible measures available to it for Kyoto implementation, the province seems less well equipped to protect its interests this time around.

In conclusion, because the incidents of the economic costs associated with implementing Kyoto will vary with the choice of instruments and decisions about the modalities of those instruments, implementation will be highly controversial. The debate over Kyoto implementation therefore invites comparisons with the energy wars of the 1980s. At bottom, both debates are debates about faimess; in one case about sharing the benefits and burdens of world price increases and in the other case about sharing the burden of controlling emissions.

We are now in a position to examine Alberta's proposals for responding to the problem of climate change.

s1 Note that while revenue sharing actually required a negotiated agreement since federal paramountcy rules seem of limited application to taxation powers (there is no conflict as such), this may be less obviously the case with Kyoto implementation since absent agreement, tle federal government may be in a position to dictale what will be a fair solution to sharing the costs of $K$ yoto implementation. The issue of federal paramountcy is discussed further, infra Part $\mathrm{V}$. See Energy Mines and Resources Canada, National Energy Program (Ottawa: Supply and Services Canada, 1980).

Reference Re Proposed Federal Tax on Exporsed Natural Gas, [1982] 1 S.C.R. 1004, aff g (1981), 122 D.L.R. (3d) 48 (Alta. C.A.) [Re Natural Gas Tax Export Tax].

Note, however, that since some older leases contained a cciling on royalty increases the province purported to excise these provisions by amending the Mines and Minerals $A c t$ thereby making it vulnerable to the argument that in these cases it was relying upon its sovereign authority to make laws rather than its owner's right to levy a royalty. See David E. "Thring, "Alberta, Oil, and the Constitution" (1979) 17 Alta. L. Rev. 69.

ss This had the potential to provide significant economic leverage insofar as any resulting shortfall would have to be made up through more expensive imports. It is much harder to identify similar provincial leverage in the context of $K$ yoto implementation. 


\section{Alberta's Pol.icy AND LEgislation}

The Prime Minister should be held to his commitment to Premiers to ensure equitable treatment across Canada, without placing undue burden on Canadians in a particular province or region.... Alberta should review its commitment to best efforts in reducing emissions. $\$ 6$

This section describes the evolution of Alberta's two key policy statements on provincial action on climate change: Alberla's Strategy for Action on Climate Change ${ }^{57}$ and Albertans and Climate Change: Taking Action. ${ }^{98}$ It then goes on to describe provincial legislative initiatives.

\section{A. The Alberta Policy Statements}

The epigraph to this section of the article recites the lead principles in Alberta's four page strategy for Action on Climate Change, released by the Cabinet Committee on Climate Change in October 1998. The committee "agree[d] with the assessment that the risk of greenhouse gas emissions contributing to climate change warrants precautionary measures - which would mean incurring prudent costs to achieve best efforts in reducing the growth in emissions," included scientific and technical research, private and public action to improve energy productivity, economic analysis, a communication plan and establishment of Climate Change Central ${ }^{60}$ as a government-private sector partnership to promote public discussion and education. Apart from Climate Change Central, the strategy did not address specific implementation measures.

The Alberta Plan emerged in $2002^{\circ 1}$ following a public consultation process. The overall strategy did not change. Nor did the overall approach. Alberta remained "committed to reducing greenhouse gas [GHG] emissions and contributing to an effective approach for responding to the risks of climate change." ${ }^{22}$ The Plan is stated to reflect "[a] collaborative approach" and "[o]ur fair share." and emissions control technology and energy conservation and efficiency. The necessity for actions "compatible with our largest trading partner - the United States" is specifically mentioned, as is collaboration on a national plan. ${ }^{64}$ The Plan does address implementation and proposes the use of specific instruments and approaches.

Actions are proposed in the following areas: ${ }^{.5}$

Alberta, Cabinet Committee on Climate Change, Alberta's Strategy for Action on Climate Change Preliminary Report (Edmonton: Government of Alberti, 1998) [Action on Climate Change].

Sbid.

Alberta, Albertans and Climate Change: Taking Action (Edmonton: Government of Alberta, 2002) [Alberta Plan].

Action on Climate Change, supra note 56 [emphasis in original].

Sec ontine: Climate Change Central <www.climatechangecentral.com>.

Alberta Plan, supra note 58.

lbid. at 5.

lbid. at 8.

Ibid.

Ibid. at 9. 


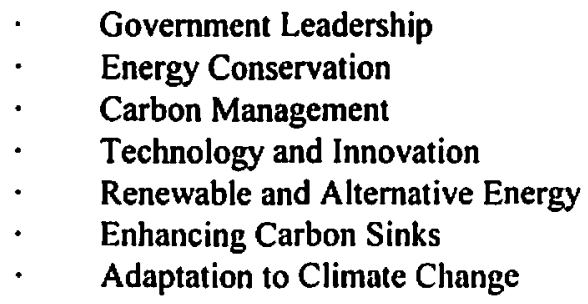

Three major techniques are proposed. The first is establishing "targets" for emissions reduction ${ }^{66}$ A provincial target of reducing GHG emissions by 50 percent below 1990 levels by 2020 is proposed. This is expressed in terms not of actual quantified reduction (the language of the Kyoto Protocol), but of emissions intensity - emissions relative to GDP. A 28 percent emissions intensity improvement by 2020 is projected, but the Plan also shows that while the reduction amounts to $60 \mathrm{MT} \mathrm{CO}_{2}$ equivalent, this represents a quantified increase over 1990 emissions. ${ }^{67}$ An intensity target, it is explained, makes sense because it lessens pressure on economic objectives, and because it will "reflect the trading relationship" with the U.S., in view of the U.S.' failure to ratify the Kyoto Protocol. ${ }^{68}$ Others question the efficacy of this approach and argue that with Alberta's projected 3-4 percent GDP growth and resulting emissions, this approach will actually lead to an increase in absolute emissions of 20-35 percent and as much as 83 percent over 1990 levels by $2020 .^{69}$ Bramley characterizes it as "a plan to increase emissions," and states that "only the absolute level of GHG emissions provides a direct measure of the impact on the global climate. The environment only "cares about' emissions; it is oblivious to GDP."

The Alberta Plan implicitly acknowledges this concern as expressed by stakeholders in the planning process."

The second technique is negotiation by the Alberta government of voluntary agreements for GHG emission reduction with specific sectors including electricity, petroleum, transportation, forestry and municipalities. ${ }^{72}$ These voluntary sectoral agreements will establish measurable targets based on emissions per unit of production, as well as baselines for performance measurement, will include monitoring, verification and reporting, and will allow flexibility for how targets are to be achieved.

Ibid. at 10 .

Ibid. at 11 .

lbid. at 12.

Matthew Bramley, An Assessmem of Alberla's Climute Change Plan (Drayton Valley, Alberta: Pembina Institute. 2002) at 5. For a review of the relative merits of absolute and intensity based emission processes see A. Denny Lillerman \& lan Sue Wing. Absolute vs. Intensity-Based Emission Caps (Cambridge: MIT Joint Program on the Science and Policy of Global Change, 2003), online: MIT Joint Program on the Science and Policy of Global Change <web.mit.edu/globalchange/inww/ MITJPSPGC_Rp1100.pdi>.

Ibid. at 4.

Alberta Plan, supra note 58 at 12.

lbid. at 15. 
To ensure fairness, regulatory "backstops" will be established and regulations will require organizations that do not sign agreements to meet the same targets. ${ }^{73}$ Specific reference is made to this approach already being taken in the electricity sector through a multistakeholder collaborative approach developed by the Clean Air Strategic Alliance (CASA). ${ }^{74}$

A third instrument to be developed is an emission trading system. ${ }^{75}$ This is intended to complement the negotiated sectoral agreements and will be coordinated with national, continental and international systems, while reflecting "Alberta's unique needs and circumstances." "76 Emission trading is discussed in the broadest sense of permitting an organization to purchase reductions from another organization that has exceeded emission targets, then apply this "offset" to its own emission reduction objectives. The Plan notes that while the reduction targets and sectoral agreements approach limits the need for purchasing international emission permits and trading, a trading system compatible with international systems will nevertheless provide flexibility for private sectors. ${ }^{77}$

Specifically, the Plan refers to a "foundation" provincial requirement that all new coalfired electricity generation plants of fset their greenhouse gas emissions to the level of a lower emission combined cycle natural gas turbine plant. ${ }^{28}$ Further, the government will develop an Emission Reduction Registry, support Climate Change Central's work on mechanisms for trading offsets related to forest and agricultural sinks, and push an already launched feasibility study on design of an emission trading system.

The final mechanism is a basket of partnership, promotion and education initiatives that include registering the government's own voluntary operations action plan with VCR Inc., establishing a Climate Change and Emissions Management Fund, supporting technological innovation, particularly through the Alberta Energy Research Institute (AERI), and establishing an energy efficiency and conservation office led by Climate Change Central. A specific initiative will involve research and development of carbon storage in geological formations, including $\mathrm{CO}_{2}$ enhanced petroleum production. ${ }^{79}$

lbid. at 17.

Ibid. See also online: Clean Air Strategic Alliance (CASA) <www.casahome.org>. The Alberta Government adopted CASA's emissions management framework for the Alberta electricity sector. sec CASA Electricity Project Team, An Eimssions Managiment Framework for the Alberta Eilectricily' Sector: Reporf to Stakeholders (Fdnionton: CASA, 2003), online: CASA <casahome org/uploads/ Emissions_Mgmt_Framework.pdt>.

Alberta Plan. supra note 58 al 18-19.

Ibid. at 18.

Ibid. al 20.

Ibid. at 18. See the Alberta linergy and Utilities Board decisions of TransAlla Utilites. 900-MII' Keephills Power Plan Expansion (12 Fcbruary 2002). ALUB Decision 2002-014 at 69, 72 : Epcor. 190-MW Genesee Power Plant Expansion (21 Decembcr 2001), AEUB Decision 2001-1II at 65 Alberta Plan, supra note 58 at 26-28. 


\section{B. BILLS 32 AND 37}

While Bill 32, the Climate Change and Emissions Management Act ${ }^{80}$ died on the order paper of the 2002 fall legislative session, its successor, Bill 37 received royal assent in 2003. ${ }^{81}$ This statute implements the key elements of the Plan for Action on Climate Change. It establishes the "specified gas emission target for Alberta" as a reduction by December 31, 2020 of "emissions relative to Gross Domestic Product to an amount that is equal to or less than 50 percent of 1990 levels." ${ }^{22}$ The Lieutenant Governor in Council may, by regulation, establish interim provincial targets and interim targets for particular gases and particular economic sectors. ${ }^{83}$

For the purposes of meeting the GHG emissions targets, the Minister of the Environment is authorized, with Cabinet approval, to enter into voluntary sectoral agreements respecting objectives and undertakings for meeting emission targets, baselines for establishing emission targets, minimum efficiency levels, maximum emission levels per unit of energy input or output and per unit of material input or product output, and a series of matters concerning agreement implementation, including schedules, monitoring, reporting, and options for meeting targets. ${ }^{84}$ Specifically mentioned is compliance enforcement including "financial and non-financial penalties."

The Lieutenant Governor in Council is authorized to make regulations respecting "emission offsets, credits and sink rights" for the purpose of achieving emission reductions "consistent with" emission targets and with sectoral agreements. ${ }^{85}$ Specific powers concern the description and nature of these rights, how they may be "distributed, exchanged, traded, sold, used, varied and cancelled" $\mathrm{As}$ and compatibility of these regulations with "similar regulatory schemes in other jurisdictions." ${ }^{\text {87 }}$ Sink rights are declared to be "property right[s]."188

Other provisions concern mandatory emission reporting, emission reduction programs, cooperation agreements with governments of other jurisdictions, establishment of a Climate Change Action Fund and broad Cabinet regulation making powers ${ }^{89}$ concerning key elements of the statutory scheme, beginning with the manner of determining GDP for the purposes of the proposed Act and establishing emission limits for specified GHGs.

While essentially the same mechanisms for GHG reduction were continued from Bill 32 to Bill 37, there are several differences. One is the removal of Bill 32's preambular assertion that plans for GHG reduction

2d Sess., 25th Leg., Alberta, 2002.

Bill 37, supra note 1.

Ibid., s. 3(1).

Jbid., s. 3(2).

Jbid., s. 4.

Ibid., s. 5 .

lbid., s. 5(b).

Ibid., s. 5(e).

lbid., s. 9.

Ibid., s. 18. 
must reflect the different circumstances of different provinces, territories and regions in Canada and sectors in the economy and must maintain or enhance competitiveness without creating an undue burden on those provinces, territories, regions or sectors, [and further that] the determination of undue burden must be made by the jurisdiction accepting the burden, as a fundamental matter of responsible government.

In a different vein, Bill 37's Preamble underscores interjurisdictional cooperation, with the Government of Alberta pledging to "work co-operatively with other jurisdictions to harmonize efforts to reduce emissions of carbon dioxide, methane and other specified gases without impairing economic growth."

A provision of Bill 37 itself provides for interjurisdictional agreements consistent with the proposed Act and the Alberta emission target for cooperative, complementary or compatible actions for emission reduction. ${ }^{90}$

Other preambular declarations in Bill 32 were reproduced almost verbatim in Bill 37. These include the assertion that the Government of Alberta "has a deep and well established commitment to protect Alberta's environment for future generation through proactive and responsible stewardship of the environment", the specifications that Alberta owns its natural resources and manages their exploration, development and production and that "atmospheric carbon dioxide and methane are not toxic and are inextricably linked with the management of renewable and non-renewable natural resources, including sinks."

Another difference is the removal in Bill 37 of all specific reference to emissions trading systems. Section 5 of Bill 32 authorized the Lieutenant Governor in Council to make regulations establishing a system of emission trading for the purpose of achieving the emission targets consistent with those targets and with sectoral agreements. ${ }^{11}$ In Bill 37, there is reference to terms and conditions on which rights may be "traded," but only in the context of powers to make regulations in relation to "emission offsets, credits and sink rights."92 However, this, along with the power to define the nature of offsets, credits and sink rights, appears sufficient to authorize establishment of an emission trading system. Moreover, the general regulation making provision includes a power "respecting the use of economic and financial instruments and market-based approaches directed to ... emission reduction and ... sequestration,"93 which may be broad enough to encompass emissions trading. But if Bill 37 can support an emissions trading system, what sort of trading system would it be? ${ }^{94}$ We have already emphasised that Alberta's policy documents and indeed the two Bills have as their target not the reduction of GHG emissions but instead the more elastic concept of emissions intensity, namely specified gas emissions relative to GDP. What then will be tradeable units under this kind of scheme and will they be compatible with the permits that are envisaged by the federal Climate Change Plan? We shall return to this question in Part $\mathrm{E}$ of the paper.

lbid., s. 8.

Supra note 80. s. 5.

Supra note I, s. 5(a)-(b).

Ibid., s. 18(1)(p).

Note that sectoral agreements (ibid., s. 4) have to be targeted at meeling the "specified gas emission targets referred to in section 3" (i.e. emissions intensity targets). The same is arguably the case for regulations passed under $\mathrm{s}$. 18, which must generally serve the purposes of the Act. 


\section{The Constitutional Framework: Legisiative Powers}

Sections 91 and 92 of the Constitution Act, 1867 empower the federal and provincial governments respectively to make laws "in relation to matters coming within the Classes of Subjects"9s enumerated in the sections. To be valid, a provincial law such as the Climate Change and Emissions Management Act (Bill 37) must come within one of the subjects enumerated in s. 92.

This language of "matters" and "classes of subjects" has led to a two step approach to the judicial review of legislation. ${ }^{\%}$ The first step is the characterization of the law or a provision of the law that is in issue. The second step is the allocation of the law as characterized to the appropriate and properly interpreted head of (in this case provincial) legislative power. The steps are not rigidly separate. Characterization does not occur in a vacuum but in the conceptual context of potentially relevant heads of power. However, as a preliminary step, judges attempt not to be constrained by constitutional concepts and language and ask, simply what is the law about? This question has been formulated in a number of ways:

What is,

the content or subject matter of the law; ${ }^{97}$

its leading feature, ${ }^{98}$

its true nature and character; 99

its true meaning or dominant feature; ${ }^{100}$ and, most commonly, its pith and substance? ${ }^{101}$

In asking these questions a court considers both the purpose and effect of the legislation. ${ }^{102}$ In some cases, this leading feature or pith and substance will be reasonably clear. But what if there are multiple features? How do the courts select? They consider the entire legislative scheme and relevant extrinsic material as discussed below. The likely effects of the legislation are relevant. ${ }^{103}$ According to Hogg, "[I]ogic offers no solution." 104 Courts appear simply to make a judgment based implicitly on some kind of functional assessment and balancing of constitutional values.

Constitution Act, 1867 (U.K.), 30 \& 31 Vict., c. 3, reprinted in R.S.C. 1985, App. II, No. 5, opening words of ss. 91 and 92 [Constifution].

Hogg. supra note 45 at 382 and literature cited.

Reference Re Anti-Inflation Act. [1976] 2 S.C.R. 373 at 450. Beetz J., dissenting [Re Anti-Infation Act).

R. v. Morgentaler, [1993] 3 S.C.R. 463 at 481 |Morgentaler].

Whitbread v. Whalley, [1990] 3 S.C.R. 1273 at 1286 [II/hitbread].

Ward v. Canada (A.G.), [2002] I S.C.R. 569 at 579 [Ward].

Union Colliery v. Bryden. [1899] A.C., 580 at 587, Watson 1.J. (P.C.), Whutbread, supra nole 99 at 1287.

Kinkalla Band v. British Columbia (Minister of Small Business, Tourism and Culture), |2002| 2 S.C.R. 146 at 17 ] (Kitkatks Band); Morgentalcr, supra note 98 at $\mathbf{4 8 2 - 8 3}$.

Global Securities Corp. v. British Cohmbia (Securitics Commission), [2000] I S.C.R. 494 at 507 [Global Securities]; R. v. Swain. [1991] I S.C.R. 933 at 998.

Hogg, supra note 45 at 384. 
A similar problem can arise at the allocation step if the leading feature is reasonably clear, but may plausibly come within several provincial and federal heads of power. There is no authoritative statement of choice criteria. However, such factors as efficiency, particularly in terms of which level of government is likely to be able to most effectively address the issues, and democratic values, such as diversity, accountability and responsiveness, have been identified by scholars. ${ }^{105}$

A final preliminary matter is evidence. Though extrinsic evidence was once rigidly excluded, courts now accept a wide range of extrinsic evidence to assist the characterization process and, should interpretation of the constitutional provisions be required, to enhance the external context for the process of purposive interpretation. ${ }^{106}$ Such evidence includes statements in the legislative debates, policy statements, formal consultation or discussion documents, technical reports and studies. Here, the relevant extrinsic evidence includes the provincial climate change plans, as well as related documents such as material issued by Climate Change Central, Alberta Energy and Alberta Environment and relevant decisions and guidelines of the Alberta Energy and Utilities Board. The federal Climate Change Plan and certain other federal documents are also relevant.

\section{Relevant Provincial, Poivers}

A number of s. 92 provincial powers "exclusively [to] make laws" are potential sources of legislative jurisdiction for the Climate Change and Emissions Management Act. A single power need not be identified. The Act may be authorized by a combination of several powers. Particular parts or elements of the Act may be based, or primarily based, on different heads of power.

Section 92(13), "Property and Civil Rights in the Province," is fundamental since it has been held to authorize regulation of land use within provinces and relevant business activity. ${ }^{107}$ "Local Works and Undertakings" 108 also appears to be relevant, as does "Management and Sale of the Public Lands belonging to the Province and of the Timber ...

Iins Ihid. at 395-96.

Iir. See ibid. at 1385-89. While long excluded, the Supreme Court confirmed in cases beginning with $R e$ Anti-Infation $A c t$, supra note 97 at 438-39, that "extrinsic" evidence, particularly government studies and reports, is admissible to estahlish the context for characterization of the legislation in question and if necessary, for interpreting the Constitution. See also Re Natural Gas Export Tax, supra note 53 at 1008; Reference Re Upper Churchill Water Rights Reversion Act 1980, [1984] I S.C.R. 297 at 315-19 [Re Upper Churchill Water Righs]. Relevant factual evidence, for example, GHG emissions data and its interpretation, is also admissible.

Hogg states that "[t|he insurance cases discussed in the previous section [particularly, Citizens Insurance v. Parsons (1881). 7 App. Cas. 96 (P.C.) and Canada (A.G.) v. Albersa (A.G.) (Insurance Reference), [1916] I A.C. 588 (P.C.)] established the proposition that the regulation of business was ordinarily a matter within property and civil rights in the province" (supra note 45 at 522 ), and adds at 738 that s. 92(13) "authorizes the regulation of land use and most aspects of mining, manufacturing and other business activity, including the regulation of emissions that could pollute the environment". citing R. v. Lake Ontario Cemen, (1973] 2 O.R. 247 (Ont. I1.C.). See also R. v. Canadian Pacific Lid., [1995]2 S.C.R. 1028; Canadian National Raihway) Ontario (Enwronmental Protection Act Director) (1991), 80 D.L.R. (4th) 269 (Ont. Div. Cl.). 
thereon." ${ }^{109}$ A residual power is s. 92(16), "Generally all Matters of a merely local or private Nature in the Province." Section 92(15) authorizes enforcement of otherwise valid provincial legislation, including regulatory offences. Finally, s. 92A(I) gives provinces exclusive authority in relation to: "(b) development, conservation and management of non-renewable natural resources and forestry resources in the province, including (c) development, conservation and management of sites and facilities in the province for the generation and production of electrical energy." However, it is unlikely that this enhances the core provincial property powers. ${ }^{110}$ The provincial power to make laws is confined to the area of the province; in other words, a province has no extra-territorial law making capacity. ${ }^{111}$

\section{E. APplication to THE ACT}

In light of these potential provincial powers to make laws, what is the leading feature or pith and substance of the Climate Change and Emissions Management Act? The starting point is the broader context of the global problem and potential consequences of climate change and the international instruments intended to address the problem - the UNFCCC and the Kyoto Protocol, both signed and ratified by Canada.

The Preamble of Bill 37 declares that the Government of Alberta recognizes that management of GHG emissions "will serve to protect Alberta's environment." Core provisions of the Bill are in s. 3, which addresses reduction of "specified" GHG emissions in Alberta. ${ }^{112}$ The language used is establishing a "target," a term that includes an aspirational element closer to "objective" than to "limit" or "standard." But s. 18(1)(b), part of the Lieutenant Governor in Council regulation making power, is more forthright. It provides for the establishment of "limits on the levels of specified gases that may be released into the environment from any source or type of source." "I' The method for establishing the target and interim targets and the timing for its achievement is emissions intensity - that is, the quantity of emissions relative to GDP. ${ }^{114}$ Section 18 (1)(d) authorizes the Lieutenant Governor in Council to make regulations "governing the maximum levels of emissions" in intensity terms, namely, "per unit of energy input or output or per unit of material input or product output for operations and undertakings in Alberta."

While the efficacy of an emissions intensity approach has been questioned, as noted above, we recall that, colourability apart, constitutional characterization is not an assessment of the efficacy of legislation. There may be measures and instruments available that will produce greater absolute emission reductions, but the question remains: is the proposed Act about reduction of emissions from Alberta sources? The answer must be yes. The intensity approach, based on provincial GDP and energy or material inputs and outputs of Alberta firms, makes it clear that the emission reduction scheme is aimed at commercial activities in

uin' Ibid., s. 92(5).

III' Hogg, supra note 45 at 734.

III Re Upper Churchill Water Rights, supra note 106. Nole that s. 92 opens with the words "In each Province" and that many of the individual heads of power refer to either "in the Province" or "with in the Province."

iI: Bill 37, supra note I, s. 3(1).

iil $\quad$ bid., s. $18(1)($ b).

iis Ibid., s. 3(l). 
the province. The legislation does not purport to have and does not have an extra-provincial reach. This conclusion is not affected by Alberta's commitments in both policy instruments and in the Preamble to Bill 37 to work cooperatively with other jurisdictions and to harmonize efforts to reduce emissions. ${ }^{115}$ The decision of Global Securities ${ }^{116}$ suggests that interjurisdictional cooperation mechanisms reasonably necessary to address a local problem are likely to be characterized as incidental extra provincial aspects of a provincial law.

Another potential "dominant feature" of Bill 37 is implementation of the Kyoto Protocol - an international legal commitment in relation to a global problem. In fact, the Alberta Plan and its implementing legislation have been criticized as being inconsistent with Kyoto, or at least not responsive to Canada's emission reduction commitments, because of its emphasis on emissions intensity. ${ }^{117}$ The fact that the legislation may not effectively address Kyoto Protocol implementation underlines the provincial scope of the emission reduction goal. The government "recognizes" that management of emissions "will serve to protect the Alberta environment," thus linking emission reduction to provincial environmental protection. ${ }^{118}$

The Preamble declarations concerning protection of Alberta's environment and that $\mathrm{CO}_{2}$ and methane are "inextricably linked" with the management of renewable and non-renewable natural resources, including sinks, also underline that the focus is on protection of the provincial environment and that the GHGs intended to be limited are, to a significant extent, a product of provincial natural resource development and use. All of this argues against the proposition that this is an upstart, subnational unit aiming at implementing Kyoto's international obligation through these core emission reduction requirements. That being said, climate change, the subject of the Kyoto Protocol, is undoubtedly the broader context of this provincial action.

The Kyoto Protocol apart, is Bill 37 really legislation addressed to Canada's interests and obligations in relation to global climate change? The Alberfa Plan states that the province "is prepared to contribute to the global objective of reducing the concentrations of greenhouse gases in the atmosphere through a set of challenging and promising actions."119 Thus, while the global objective is acknowledged, the actions promised are explicitly provincial with a view to "position[ing] the province's citizens and businesses to compete in a carbon emissions - constrained future and ... help the world meet its energy requirements with sharply reduced emissions over the longer term." 20 This is analogous to provincial laws aimed to strengthen the provincial economy that also promote and strengthen the national economy and Canada's overall internal and international trade. It is one thing for the provincial legislature to make a law to establish a program or institution explicitly intended to have effect at the national and international levels and to modify or displace federal initiatives - such a law is likely invalid. But it is another thing for the provincial legislature

IIs Ibid. Preamble.

III. Supra nole 103 at 509-10.

IIT Bramley, supra nole 69 al 3-6

Itx Bill 37. supra nole 1. Preamble.

(11) Alberta Plan, supra note 58 at 5.

$130 \quad$ Ibid. at 9. 
to make a law that is addressed to the citizens and businesses in the province and that may affect international matters - such a law is likely valid.

Are there other possible leading features of Bill 37? Is it economic development legislation aimed at improving the financial position of Alberta-based corporate GHG emitters? The Preamble to Bill 37 speaks to "providing certainty to all sectors of the Alberta economy," to cooperative efforts with other jurisdictions to reduce emissions "without impairing economic growth" and to "leading-edge innovation in environmentally sustainable technologies." Provincial industrial benefits may be an effect, but the nature of this effect is uncertain depending on the ability of firms to achieve emission reductions or limitations and thereby generate valuable tradeable credits. But whether benefits are produced or emission reduction costs are imposed on firms, the effects will be a consequence of emission reduction actions.

If the central feature of Bill 37 appears to be GHG emission reduction to protect the Alberta environment, is this appearance belied or qualified by the implementation techniques chosen, namely voluntary sectoral agreements, emission offsets and trading and creation of property rights in sinks? All are instruments relevant to and at least potentially appropriate for achieving emission reduction goals. This is shown by the ample literature on these instruments as techniques for GHG reduction. If one asks, "Why these instruments? What is their purpose?" The short answer must be, GHG emission reduction.

Incidental effects can be identified. One is the creation of valuable forestry and agricultural sink rights. But these sink rights are not an end in themselves; they are an incentive for actions likely to lead to GHG emission reduction. The same reasoning applies to other types of emission offset credits that may be created by any emissions trading scheme.

As outlined above, the Bill contains no specific provisions to establish or authorize the establishment of an emissions trading system. The fact that it is a serious interpretive question, whether the references to "emission offsets" and "credits" and to "the use of economic and financial instruments and market-based approaches" authorize the creation of a fully tailored emissions trading scheme, suggests that it is unlikely that establishment of such a scheme is the pith and substance or central feature of the legislation.

\section{F. Allocation}

What then are the heads of provincial legislative power to which the proposed Act should be allocated? We begin with a presumption of constitutionality. ${ }^{121}$ From here, the most obvious candidate provincial power is s. 92(13), property and civil rights. Property of GHG emitters is affected in the manner of its use by the effective restriction on GHG producing uses. To the extent that emission offsets or credits under trading scliemes authorized by Bill 37 are created, all with a view to reducing emissions, these are new property or contractual civil rights. Similarly, sectoral agreements contemplated by the Bill will create new species of civil rights.

12. Nova Scotia Board of Censors v. McNeil, [1978] 2 S.C.R. 662, cited in Reference re Firearms Act (Can.), [2000] I S.C.R. 783 at 802 [Firearms Reference]. 
Also relevant is s. $92(10)$, local works and undertakings, which are affected in their operations and perhaps in their viability by the emission reduction instruments created by the Bill. Section 92(16), matters of a local and private nature, provides residual support. To the extent that sink rights are owned by the Crown, at least, as discussed below, before the resource is severed, provincial public property ownership provides legislative authority, along with s. 92(5), "Management and Sale of Public Lands belonging to the Province and of the Timber and Wood thereon." The latter is directly relevant to forest sink rights. The determination of which head of power accommodates a particular law is, as the Supreme Court of Canada reminded us in the Firearms Reference, "not an exact science."122

In assessing which head or heads of provincial power the substantive provisions of Bill 37 may come within, the effect of the legislation on federal powers may be considered. ${ }^{123}$ Here, however, this is not a serious issue because the primary effect is on industrial property and operations and the harm caused by these GHG emissions within the province. Emission credits trade may extend beyond the boundary of the province, but the objective is not trade per se but rather trade in specifically tailored rights for the purpose of facilitating effective and efficient provincial source GHG emission reduction.

There is no obvious head of federal power, as there was, for example, in the Kitkatla Band case where, in considering provincial heritage conservation legislation, the Supreme Court said that "one cannot escape the fact that the impugned provisions directly affect the existence of aboriginal heritage objects, raising the issue of whether the provisions are in fact with respect to Indians and lands reserved to Indians, a federal head of power under s. 91(24) of the Constitution Act, /867."124

There is no head of federal power immediately apparent as a potential source of legislative jurisdiction for this provincially focused GHG emission reduction scheme under Bill 37 . The federal trade and commerce power in its general trade aspect must be considered, and this is done below. Trade jurisdiction is particularly relevant to the emission offset credit trading aspect of the scheme. Beyond that, any attempt to bring the entire emission reduction scheme within federal general trade jurisdiction encounters concerns about balance and respect for the principle of federalism. ${ }^{125}$

\section{G. Excursus: tile Role of Provinciat. Property Rigitts}

A significant theme in provincial statements supporting Alberta's climate change proposals (and similar statements seeking to undermine federal legislative competence to implement Kyoto commitments) has been a set of claims that the provincial government's position is somehow strengthened by its ownership of natural resources within the province. Implicit here, if not explicit, is the idea that provincial property rights provide some sort of

Firearms Reference, ibid. incidental

Kitkatla Band, ibid. at 177.

12: Kilkatla Band, supra note 102; Firearms Reference, ibid. al 812-13, where potential undue intrusion by the federal legislation on provincial powers was considered and found to be not more than merely

Ward, supra note 100 at $583-84$ and authorities cited 
protective cover against the application of federal laws designed to implement Kyoro. The purpose of this excursus is to examine the validity of that claim.

The claim starts with the proposition that the Constitution allocated Crown property within each of the provinces to the Crown in right of the province rather than to the Crown in right of Canada. ${ }^{126}$ It also allocated to the provinces the power to make laws for the management and sale of public lands through s. 92(5). The claim gains further support from the observation that the Constitution deals separately with the allocation of legislative powers and property rights and the related proposition that the allocation of legislative powers does not carry with it any property entitlement. ${ }^{127}$

The argument that provincial ownership rights serve to insulate the provinces from the reach of federal regulation is a familiar one insofar as similar claims were made during the 1970s and 1980s as part of provincial responses to the National Energy Program. Merv Leitch, the former provincial Minister of Energy and Natural Resources, put the claim very explicitly in 1974: "In my view the key to the answer to nearly all questions of jurisdiction over natural resources lies in the ownership given to the provinces by The British North America Act.... a provincial government under the constitution has vastly greater control over the natural resources it owns than it does over natural resources it doesn't own."128

It is harder to find such a clear articulation of the provincial reasoning in the Kyoto discussions but the public pronouncements of Premier Ralph Klein, his Ministers and MLAs in the legislature that confirm the claim has not been abandoned. For example, speaking to the second reading of Bill 32, Premier Klein observed, "That leads me to the second purpose of Bill 32. In addition to reaffirming Alberta's commitment to take action on global warming, this bill will also help protect Albertans from the federal government's Kyolo agenda... We will protect ... Albertans ... by reinforcing the province's ownership and control over natural resources." 129 Similar views were expressed by other government members during the debates on the two Bills. ${ }^{130}$

13. This follows from s. 109 of the Constifution, supra note 95, and the Natural Resources Transfer Agreements of 1930, which placed the Prairic Provinces in the same position as the original provinces of Confederation. See Re Natural Gas Export Tax, supra note 53.

127 Thus the allocation of the head of "I.ands reserved for the Indians" (s. 91(24)) to the federal Parliament did not convey the Crown's radical title to lands burdened by an unextinguished aboriginal title to the federal Crown (St. Catherine's Milling and Lumber v. The Queen (1888), 14 App. Cas. 46 (P.C.)), and likewise allocation of "Sea Coast and Inland Fisheries" (s. 91(12)) to the federal Parliament did not authorize Parliament to issue seabed fishing leases conferring the exclusive right to fish to areas located within the province - it did however authorize parliament to created a limited entry licensing scheme: Canada (A.G.) v. Ontario (A.G.), [1898] A.C. 700 at 714 (P.C.). As quoted in J. Peter Meekison, ed., Canadian Federalism: Myth or Reality, 3d ed. (Toronto: Methuen, 1977) at 172-73, cited in William D. Moull, "Natural Resources: Provincial Proprietary Rights, the Supreme Court of Canada. and the Resource Amendment to the Constitution" (1983) 21 Alta. L. Rev. 472 al 473. I.cgislative Assembly, Alberka /lansard. 42 (26 November 2002) at 1534.

Sec L.egislative Assembly. Alherla Hansard, 43 (26 November 2002) at 1551 (Mr. Doerksen): "Clearly. in the preamble what we are selling out is that (lie government of Alberta by its constitutional authority has the owizership of natural resources and the rights to manage the exploration, development, production of those resources for its oww benefit. Further, we go on to assert the fact that we are also asserting our ownership position in the sinks"; and the Honourable Lorne Taylor, Minister of the Environment, in speaking to Bill 37 at second reading, Legislative Assembly, Alberta llansard, 36 (28 
But do these claims hold water or are they the legal equivalent of throwing sand in the air? In our view it is the latter and we propose to demonstrate this by answering three questions: (1) does the provincial climate change legislation expand provincial ownership claims to natural resources in the province; (2) even if it does, how would that improve the provincial government's legal position in the context of climate change negotiations; and (3) can the province claim an immunity from the application of federal laws by virtue of its ownership position over natural resources?

\section{Does Bill. 37 Expand Provincial. OWnership Ci.aims?}

One of the techniques used by the province to strengthen its position during the energy wars was to extend the scope of its ownership claim as part of the Re Natural Gas Export $\mathrm{Tax}^{131}$ It did this by essentially inventing a factual scenario that contemplated an oil and gas company acting as a contract operator for the province for production of the province's natural gas and then the subsequent export of that gas. The Supreme Court held that the tax could not apply to this gas since it was owned by the province and was therefore entitled to the protection of $s .125$ of the Constitution.

Has the province adopted a similar technique in Bill 37? Our examination of the Bill suggests that, notwithstanding the rhetoric of the speeches, the Bill has made little effort to extend provincial ownership claims. In fact, apart from one general recitation of ownership claims in the Preamble, ${ }^{132}$ the only other explicit reference to ownership rights occurs in the context of sinks. Section 9 of Bill 37 provides that "[a] sink right is a property right." The Bill also defines the terms "sink" and "sink right":

(e)

"sink" means

(i) a component of the environment that removes or caplures specitied gases from the almosphere through natural processes and includes, without limitation. plants and soil, and

(ii) a geological formation or any constructed facility, place or thing that is used to store specified gases:

(f)

"sink right" means the legal interest, and any commercial or other interest, in a sink: ${ }^{133}$

But even having defined these terms, there is no clause vesting sink rights in the Crown in right of the province, nor any regulation making power purporting to authorize such a vesting. ${ }^{134}$ Consequently, one is left with the conclusion that ownership of the sink rights will vary depending upon who, from time to time, owns the "component of the environment" or

April 2003) at 1275: "[The Bill] clearly reinforces our position (lat the government of Alberta on behalf of all Albertans owns and is responsible for the exploration, development, and production of natural resources in the province."

Supra note 53.

Bill 37. supra note 1. para. 2. "WHFREAS the Government of Alberta owns natural resources in Alberta on behalf of all Alberians and manages the exploration. development and production of renewable and non-renewable resources in Alberta."

Ibid., ss. I(e)+(f).

There is notling in the Bill to parallel. for example, the longstanding provisions in waller resources and public lands legislation vesting water riglts and rights to the beds of waters in the Crown: Water $A C$, R.S.A. 2000. c. W-3, s. 3(2); Public lands Act. R.S.A. 2000, c. P-40. s. 3. 
the geological formation or constructed facility that serves to remove, capture or store specified gases. ${ }^{133}$

In sum, notwithstanding the broad claims that the province is using Bill 37 to shore up the provincial property rights argument, it is clear that there is nothing in the text of the Bill that suggests a dramatic expansion in provincial ownership claims. The province has not arrogated to itself property rights that were previously vested in private citizens. At most, the province has clarified the claim that sink rights are a form of property thereby facilitating trading.

If the province has not made an expansive claim to appropriate the new sink rights to itself, neither has it used the Bill to extend its ownership claims to conventional and nonconventional resources. The limitations of the provincial ownership position here are well understood. The involvement of private capital in the exploration for, and production of, provincially owned carbon resources typically involves the transfer of ownership of the resource at some point to the Crown lessee or licensee. There is nothing inevitable about this way of organizing the coal, forest and oil and gas industries of the province, but to organize them in any other way would be profoundly unconventional and controversial. But absent such a change, while the province may begin as the owner of the carbon resource in the ground as real property, at some point in the extractive process the property will always be transformed from real property to personal property, and that transformation will ordinarily coincide with a transfer of ownership to a private party.

To conclude: (1) Bill 37 does not significantly expand provincial property claims. (2) At most it clarifies the point that carbon rights should be conceived of as a species of property. (3) Carbon rights may be owned either by the province or by a private party - which party is the owner will initialiy depend upon who owns the resource associated with the carbon rights claim (for example, the land on which the timber is growing). (4) Bill 37 does not change provincial ownership claims with respect to conventional and non-conventional oil and gas resources. (5) While the provincial Crown may own such resources (to the extent that patent has not been granted to a third party) while they are in the ground, at some point the provincial ownership claim will be lost when such resources are transformed from real property to personal property through acts of severance by third parties.

In some cases these will be owned by the Crown in right of the province, in some cases by the Crown in right of Canada (e.g. National Parks) and in some cases by private parties as part of their existing land titles registered under the Land Titles ACI, R.S.A. 2000, c. L.5. In still other cases, where the unpatented title remains with the Crown but various third parties have acquired a varicty of resource rights, the determination of who, as between the Crown and the resource rights holder, is the owner of the "sink right" may depend upon the specific terms of the grant and its supporting legislation; in uther words, there will be some interesting and difficult interpretive issues to resolve as we move to implementation. In any event, it is probably most usefil to think of s. 9 of the Bill as a "for grealer certainty" provision for it is entirely possible that if sink rights had come to be the subject of widespread commercial trading that a court might have decided that "sink rights" fulfilled enough of the characteristics shared by other property rights that they should be treated as property rights: see Bruce Ziff, Principles of Properny Low, 3d ed. (Scarborough: Carswell, 2000) at c. 1, passim. 


\section{But How Woul.d Provincial OWNership Claims IMPROVE THE PROVINCE'S LEGAL. POSITION ANYWAY?}

If we assume that Bill 37 enhances provincial ownership claims in a way that is relevant to the Kyoto debate, how might that strengthen, if at all, the province's legal position? It is well understood that the Crown in right of the province, as the owner of resources, has a broad range of rights and powers just as does a private owner. Professor Hogg puts the point this way:

As a legal person, the Crown in right of Canada or the Crown in right of a province has the power to do anything that other legal persons (individuals or corporations) ean do. Thus, unless there are legislative or constitutional restrictions applicable to a piece of public property, it may be sold, mongaged, leased, licensed or managed at the pleasure of the responsible government, and without the necessity of legislation... Moreover, in the role of proprietor, the Crown can (subject to market conditions) insist upon the inclusion in leases, licences or other instruments of any terms that a private proprietor could insist upon. These include terms that in other contexts would be outside the province 's power to impose by legistation ${ }^{136}$

Professor Hogg goes on to point out that the provincial Crown has more extensive authority over resources that it owns, than it does over resources that are owned by private proprietors, principally because, as owner, the province may resort to imposing its will on licensees, lessees etc. by the terms of the contract and need not resort to legislation, primary or delegated. ${ }^{137}$ Examples include the power to impose conditions regulating production or requiring the payment of a royalty as varied from time to time by the Crown.

While these powers afforded the provincial Crown important strategic opportunities during the energy wars, they do not appear to afford similar strategic opportunities in the context of the climate change debate. What would be the sorts of terms and conditions that the Crown might seek to insert in provincial resource tenures? Traditional conditions, such as those requiring processing before removal from the province, ${ }^{138}$ or cabinet approval before removal of gas resources from the province or the waiver by Crown corporations of any immunities that they may claim, hardly seem to have any purchase in the context of Kyoto implementation. Furthermore, any more targeted conditions that one might consider (for example, a condition that the tenure holder not participate in a federal emissions trading scheme) would likely be held to reach beyond the scope of general disposition legislation. ${ }^{139}$

In sum, provincial ownership of resources and sinks may enhance the scope of provincial authority but not in a manner that is relevant to the climate change debate and Kyoto implementation.

14. Hogg. supra note 45 at 707-708 [footnotes omitted] [emiphasis added].

in Bbid.

in Smylie v. The Queen (1900), 27 O.A.R. 172 (Ont. C.A.); see also Brooks-Bidlake and IVhitrall l.dd. v. British Columbia (A.G.). [1923] A.C. 450 (P.C.) (timber licence granted for a year on the condition "that no Chinese or Japanese shall be employed in connection therewith" - the validity of the condition was upheld; the Privy Council held that while Parliament might have the exclusive authority to muke laws in relation to naturalization and aliens (s. 91(25)) this did not preclude the province from imposing conditions relating to the management of the public property of the province.)

119 Fisheries Association of Newfoundland and Labrador Led. v. Newfoumdland Minister of Fisheries. Food and Agriculiure) (1996), 142 D.L.R. (4th) 732 (Nfld. S.C. (A.D.)). 
3. Can the Province Cl.aim an IMmunity from the ApPl.jCation OF FEderal LaWS BY VIRTUE OF ITS OWNERSHIP POSITION?

The rights and powers associated with ownership express part of the picture; we now need to inquire as to whether provincial ownership claims allow the province to insulate itself from a federal climate change program. Can the province claim a form of immunity? There are two aspects to this claim: immunity from taxation and the more general idea of interjurisdictional immunity.

\section{a. Immunity from Taxation}

Section 125 of the Constitution articulates a limited form of immunity of provincial and indeed federal property:

No Lands or Property belonging to Canada or any Province shall be liable to Taxation.

In order to trigger the immunity the lands or property must be owned by the province and the measure in question must be a taxation measure and not some other form of licence fee or other form of general regulation. ${ }^{140}$ It is evident therefore that the section does not confer any general immunity on the province or licensees of the province from a federal regulatory scheme. ${ }^{141}$ Furthermore, given our conclusion above that any provincial ownership interest in a resource will ordinarily be lost from the moment of severance, the section will not likely offer protection from a carefully crafted carbon tax that focuses on producers or emitters.

\section{b. Interjurisdictional Immunity}

A claim of interjurisdictional immunity is a claim that while a regulatory scheme may be valid (that is, not ulira vires that level of government ${ }^{142}$ ) it is simply inapplicable to that subject. The concept is based on the "principle that each head of federal power possesses an essential core which the provinces are not permitted to regulate indirectly."143 A well recognized example is that provincial labour laws may not apply to federally regulated interprovincial undertakings where such laws would affect the core of that undertaking. ${ }^{144}$ The concept of interjurisdictional immunity has undergone something of a revival in recent years and has been extended beyond its origins in the protection of federally incorporated companies and interprovincial works and undertakings. ${ }^{145}$ The concept applies to shield

Re Natural Gas Export Tax, supra note 54 at 1032-34.

Ibid.

The arguments of validity or inapplicability may be made in the alternative: Nemaiah Valley Indian Band v. Riverside Forest Products Lid., 2003 BCSC 249.

Ordon Estase v. Grail, [1998] 3 S.C.R. 437 at para. 83 [Ordon Estate].

Bell Canada v. Québec (Commission de la Santé de la Sécurisé du Travail), [1988] I S.C.R. 749. A provincial law may also be inapplicable insofar as it purports to have an impermissible extraterritorial effect: Unjfund Assurance v. Insurance Corp. of British Columbia, [2003] 2 S.C.R. 63.

Sec Ordon Estate, supra note 143; R. v. Kupchanko (2002). 209 D.L.R. (4th) 658 (B.C.C.A.) (provincial law purporting to prohibit certain conveyances within the Columbia Wetlands Wildlife Management Area inapplicable to vessels operating in navigable waters) (navigation and shipping): Canada Morigage and Housing Corp. v. Iness (2004), 236 D.L.R. (4th) 241 (Ont. C.A.) [Iness] (provincial human rights Code held to be inapplicable to the terms and conditions of a $\mathrm{CMHC}$ operating 
legislative powers, but in doing so it may also shield federal Crown property. This much seems to be clearly established in relation to federal Crown property that is the subject of $s$. 91(1A): public debt and property. For example, the Ontario Court of Appeal in Mississauga (City of) v. Greater Toronto Airports Authority ${ }^{146}$ held that provincial laws, including the provincial building code and provincial development charges legislation, were inapplicable to construction activities at Pearson International Airport because such laws affected a vital or essential or integral element of federal public property. ${ }^{147}$ One of the key features of the doctrine of interjurisdictional immunity is that it does not require that federal legislation has occupied the field before its operation is triggered. ${ }^{148}$

For our purposes, however, there is a key threshold question. ${ }^{149}$ Can a province ever claim the benefit of the doctrine of interjurisdictional immunity? Can a province, for example, claim that there is a core content to s. 92(5), "Management and Sale of Public Lands," so as to render otherwise valid federal laws that interfere with that content inapplicable? Hogg's position on this point is as follows:

There is no case applying the doctrine of interjurisdictional immunity to federal laws in order to protect provincially-incorporated companics or provincially-regulated undertakings. The doctrine ought to be reciprocal, because the provincial heads of legislative power are just as exclusive as the federal heads of legislative power, although it is true that the federal heads are paramount in the event of a conflict between federal and provincial laws. There have occasionally been suggestions that the doctrine is reciprocal, but the weight of authority is the other way. Probably, therefore, a federal law in relation to a federal matter may validly extend to the status or essential powers of a provincially-incorporated company, or to the vital part of a provincially regulated undertaking. ${ }^{150}$

grant imposed as an excrcise of the federal spending power); De/gamuwhw v. British Columbia, [1997] 3S.C.R. 1010 (Indians and L.ands Keserved for Indians); and see Nigel Bankes, "Delgamuuku, Division of Powers and Provincial L.and and Resource Law: Some Implications for Provincial Resource Rights," Case Comment (1998) 32 U.B.C.L. Rev. 317.

IN. 192 D.L.R. (4th) 443.

117 lbid. at paras. 62-79, s. 91(1A) serves as a "subject matter limitation on provincial legislative power." The Court noted that the airport could claim the immunity even though the airport authorities held the land on a long term lease from the federal Crown: "The Crown has a continuing property interest in the leased land, which would be affected by provincial property development legislation" (ibid, at para. 7l). The Court also held the provincial laws inapplicable on the basis of two other lieads of federal power: the aeronautics power (peace, order and good government) and the federal undertakings power. The case also affirmed that the relevant test is "affects a vital or essential or integral" element of a federal power rather than the older and more restrictive tests of "impairs," "interferes," or "paralyzes" or "sterilizes" (ibid. at para. 41).

I+M Jid. at para. 39.

144 We focus here on the threshold question, but even if the province could meet this hurdle it would still have to demonstrate: (1) the core content of s. $92(5)$ and (2) that the federal law affected an essential or integral element of that core content. Just as there are no federal enclaves within the provinces, it is cven clearer that there is no area of a province that is immune from federal law. The doctrine of interjurisdictional immunity is at most a "subject matter limitation." A federal regulation (c.g. a carbon permit requirement) that increases the cost of an activity carried out on a provincial lease of Crown lands or resources will not, on its own, amount to an impermissible eflect on the core content of s. $92(5)$.

|s| Supra note 45 at $409-10$ [footnotes omitted][emphasis in original]; the looseleal cdition is to the same effect. We are not aware of any cases post 1997 that apply the doctrine to provincial heads of power. See also Hogg's discussion, ibid. at 287-88, dealing with the general problem of federal laws binding the provincial Crown. 
We concur with Hogg's conclusion. It is, for example, confirmed by the long-standing acceptance of the federal Parliament's authority to provide for the expropriation of provincial lands for legitimate federal purposes (such as railways ${ }^{151}$ and pipelines). It is less clear to us that the "doctrine ought to be reciprocal." We think that there are good reasons for thinking that, at the very least, the doctrine, if applicable at all, should apply somewhat differently to the provinces. For example, even if s. 92(5) has a core content that federal legislation should not ordinarily be able to affect, this reasoning should not extend to federal rules that are designed to curb spillover problems (for example, water pollution or air pollution) arising from the use of provincial resources.

In conclusion, the provincial government may claim that its property is immune from federal taxation but this immunity expires once the ownership of provincial resources passes to private parties. There is no basis on which the province can claim a more extensive immunity from federal laws based on the interaction of provincial ownership rights and s. 92(5). Our overall conclusion, therefore, is that provincial ownership claims are largely irrelevant to any informed debate on Kyoto implementation.

\section{Federal. Proposals}

As indicated in the introduction to the article, the purpose of this section is to outline the current federal proposals for the purpose of reaching some preliminary assessment of the compatibility of the federal and provincial schemes.

The federal plan for implementing the Kyoto Protocol continues to evolve but we have yet to see specific implementing legislation. The clearest and most recent articulation of the federal policy is the November 2002 Climate Change Plan for Canada. ${ }^{152}$ The Plan suggests that it is based on six key principles:

It must be a made-in-Canada approach that is based on collaboration, partnerships and respect for jurisdiction. The Plan emphasizes the extensive consultations that have been held with territorial and provincial governments, industry and non-governmental organizations (NGOs).

There must be a reasonable sharing of benefits and burdens requiring responsible investment by all. No region or jurisdiction of the country should be asked to bear an unreasonable burden.

The approach must be transparent. The approach should be adaptive and evolving yet should not create an unacceptable level of uncertainty. 
- The Plan should minimize mitigation costs and maximize benefits. In order to do so all orders of government need to work together "combining the opportunities available to governments within their respective jurisdictions." 153

The Plan should promote innovation.

The Plan should manage risks responsibly.

There is considerable emphasis in the Plan on the desirability and need for federal/provincial/territorial cooperation in the implementation of the various steps of the plan and the use of appropriate policy instruments. However, the Plan also recognizes that in some cases governments will take independent action within their own jurisdiction. In others, bilateral approaches may be preferred, while in still others a multilateral approach will be the most effective. The Plan itself describes three steps. Step I provides a description of actions currently underway and estimated to yield reductions of $80 \mathrm{MT} .{ }^{154}$ Included under this heading are measures taken by governments themselves to achieve energy efficiencies and to promote renewable and alternative sources of energy. ${ }^{195}$ It also includes measures taken by the private sector as part of the Voluntary Challenge and Registry. ${ }^{156}$

Step II comprises proposed new actions. ${ }^{137}$ Here the Plan identifies three priority areas: the transportation and building sectors, industrial emissions and the purchase of permits on the international market. These proposed measures are discussed in greater detail in the following sub-sections. Step III is described as "The Remainder."158 Here the Plan identifies that there is a gap between the current and proposed measures and Canada's Kyoto commitments and proposes a variety of additional measures that might be considered for closing this gap.

Overlapping the Plan's discussion of the three steps, the Plan also proposes the use of five different policy instruments to achieve concrete progress within the priority areas: innovation and technology investments, infrastructure investments, a partnership fund, covenants and emissions trading by industry and what are referred to as targeted measures. ${ }^{159}$ The first three of these policy instruments, and perhaps especially the fifth, engage what is generally termed the spending power. ${ }^{160}$ In each case, many of the policies that the federal government wishes to encourage (energy efficiency, integrated energy management systems for buildings) and

ist lbid it 10.

ist $\quad$ bid. at 12.

is5 National Climate Change Secretariat (Canada), Canada's National /mplementation Strateg] on Climente Change, (Ottawa: National Climate Change Process, 2000) at 8.

13. See online: Canada's Climale Change: Voluntary Challenge and Registry Ine. <www.ver-mvr ca>.

1:" Climate Change Plan, supra note 4 at 12.

Is: Jbid. at 14 .

19.) Sec ibid. at 15-17.

teat The programs may involve direct or conditional payments or. in the case of targeted measures. maly involve adjustments to the existing taxation regime. e.g through acceleraled depreciation allowances or exemptions (e.g. excise tax exemption for ethanol in gasoline). Thus. while the federal government states that it does not plan to implement $\mathrm{A}^{\prime}$ yoto through the introduction of a new tax sucli as a carbon tax, it has certainly not ruled out adjustments to existing taxation instruments. Any such meisures are obviously within the federal government authority for direct and indirect taxes under s. 91(2). 
particular projects (public transit investments for cities) will fall squarely within provincial jurisdiction. However, it has long been accepted that this does not preclude the federal government from offering financial incentives designed to encourage provincial and municipal governments to take up the challenge, whether such incentives are introduced through explicit incentive programs or through adjustments to taxation schemes. ${ }^{161}$ The most constitutionally contentious part of the federal government's scheme therefore is the proposed introduction of a trading scheme, ${ }^{162}$ and we therefore propose to focus on this scheme in the following paragraphs.

The basic elements of a trading scheme are well understood and involve the imposition of a cap on GHG emissions, an initial allocation of entitlements to make $\mathrm{GHG}$ emissions and a method for trading those entitlements. The cap may be adjusted over time. Along with taxation schemes, trading schemes are generally considered to be the most economically efficient method of achieving Kyoto targets. We have also seen that the provincial government recognizes the efficiencies of trading schemes and therefore provides authority, at least obliquely, for their introduction within Bill 37 .

But even though there is widespread agreement on the value of cap and trade as a preferred instrument for achieving emission reductions, there are many decisions that have to be made before such a scheme can be put into place. Some of these decisions are practical (for example, what should be the scope of the trading scheme - major emitters only or as broad as practical?), while others raise issues of fairness or equity (for example, should permits be issued gratis? and if so to all emitters or just to emitters that face competition with producers in non-Annex I countries who have made no Annex B commitments and to producers who might suffer significant capital losses?). These issues have been studied broadly, notably by the Tradeable Permits Working Group (TPWG) but that group had relatively little to say about the legal issues. ${ }^{163}$

The key issues for present purposes are the following: (1) What does the scheme look like? (2) What federal heads of constitutional power are potentially available and what federal proposals support a particular characterization of legislation that might emerge? (3) Given what we know, and assuming a constitutionally valid federal scheme, will the federal

1.1 Winterhaven Stables Lid. v. Canada (A.G.) (1988), 62 Alta. I.R. (2d) 266 (C.A.) (Wimterhaven Stables]: (1) it is lawful for Canada to raise revenues through direct taxes even though some of those monies will be used for programs that fall within provincial jurisdiction, and (2) once the monies are raised the monies constitute federal property and can be allocaled subject to terms and conditions. Iness, supra note 145, see especially paras. 29-36; Hogg, supra note 45 at 157-62; E.A. Driedger, "The Spending Power" (1981) 7 Queen's L.J. 124; and Andrew Petter, "Federalism and the Myth of the Federal Spending Power" (1989) 68 Can. Bar Rev. 448.

16.2 See Philip Barton, "Economic Instruments and the Kyoro Protocol: Can Parliament Implement Emissions Trading Without Provincial Co-operation?" (2002) 40 Alta. L. Rev. 417.

16. TPWG, Options Report, supra note 6 at 58. The Report noted as follows: (1) Specific authority to apply a Tradeable Emissions Permits (TEP) system for GHG does not exist. (2) Authority to create such a system might be found at the federal level in the POGG power, the criminal law power and in the trade and commerce power, and at the provincial level in the property and civil rights power. (3) Existing legislation might be used to deal with the generic issues associated with all commodity trading systems (e.g. commercial law and securities law). (4) The cost effectiveness of a TEP scheme would be enhanced if there were common requirements for permits across Canada and integration with international trading schemes. 
and provincial schemes be incompatible? (4) If the schemes are not compatible, how should the incompatibility be resolved?

\section{A. What DoES THE SCHEME LOOK LIKE?}

The federal Climate Change Plan offers only the barest outline of the proposed trading scheme. The first discussion of the scheme occurs under the heading of "Covenants and Emissions Trading." 164 From this and other references ${ }^{165}$ we glean the following elements: (1) the cap (referred to as targets) will be established through covenants (which we infer to be simply agreements with industry on a sector by sector basis), (2) while the targets will be negotiated, the Plan contemplates that the cap plus trade scheme will produce reductions of $55 \mathrm{MT} ;{ }^{166}(3)$ the sectors identified so far are: thermal generation of electricity sector, the oil and gas sector (upstream, processing, refining, gas utilities and pipelines), mining, pulp and paper production, chemical production, iron and steel production, smelting and refining, cement and lime production and glass and glass container production; (4) the Plan does not indicate how the $55 \mathrm{MT}$ will be allocated to these sectors but it does indicate a breakdown of the current responsibility for GHG emission within the industrial groupings; (5) the Plan indicates that the covenants will be sensitive to competitiveness issues in the sector "and could address a number of elements, such as emissions intensity undertakings"; ${ }^{167}(6)$ the Plan recognizes the principle that companies that have taken early action to achieve GHG reductions should not be disadvantaged by the implementation of any such scheme; ${ }^{168}$ (7) additional sectors (forestry, agriculture and possibly the landfill) would be able to sell credits into the system; ${ }^{169}(8)$ the covenants will have regulatory or financial backstops enforceable against those who fail to enter into covenants and free ride (we take this to mean that any contractual instrument will carry an exemption from a levy that might otherwise apply); (9) trades will be permitted within the cap to allow participants to meet their commitments either through emission reductions or by purchasing entitlements; $(10)$ the emissions trading scheme will be linked to the international market created under the Kyoto Protocol and presumably trades would be permitted not just within sectors but across sectors (that is, the permits should be completely fungible); and (11) recognizing the potential for high transaction costs, the Plan promises a scheme that is "administratively efficient and clear."

The discussion of the scheme within the Plan contains a plethora of statements to the effect that continuing discussions and consultation will be required on a number of matters "to clarify the architecture of a workable, efficient and effective domestic emissions trading system.""171

\section{Ibid. at 12.}

w. The Plan contains the explicit statement that "The Govemment ... agrees that the target under emissions trading will not be more that $55 \mathrm{MT}$. Any amounts beyond that target would be achieved through incentives" (ibid. at 32).

in, Ibid. at 31 .

ins Ibid. at 32

u. Ibid. at 41: "Investments that enhance the business-as-usual sink beyond the estimated $30 \mathrm{MT}$ [current carbon sink capacity based on continuing current management practices] would produce credits for sale to the benefit of investors and owners through the proposed offset system."

13i. Ibid. at 30

131 Ibid. at 17. 
Informal "non-papers" posted to the Natural Resources Canada web site" in late 2003 and early 2004 address a number of these issues, including the allocation of targets to large industrial emitters, the structure and issues of Climate Change Covenants, the distribution of permits and the timing and frequency of remitting permits to demonstrate compliance or "true-up." Most important for our purposes is a document titled "Overview of Legislation."173 It acknowledges the need for legislation to implement the large final emitters (LFEs) policy regime proposed in the federal Climate Change Plan either as a new part to Canadian Environmental Protection Act, $1999^{174}$ or a new Climate Change Implementation Act. ${ }^{175}$

The "essentials" of the legislation are expected to include the following "key elements":

I. LFEs will be required to quantify greenhouse gas (GHG) emissions and associated output using specific protocols to be set out in regulation.

2. LFEs will be required to report their GHG emissions and associated output in a manner set out in regulation.

3. L.FEs will be prohibited from eminting GHGs without a permit.

4. Permits will be provided to LFlis through allocation methods defined in regulation. In the case of the first commitment period, a certain number of permits (equal, on average, to 85 percent of forecast 2010 emissions) will be provided free of charge by the government. The exact number for each industry will be set out in regulation.

5. LFEs will have to remit an amount of permits equal to their actual GHG emissions for a given compliance period.

6. Companies that cannot reduce their emissions sufficiently suclt that the free distribution of permits covers their needs will be able to buy permits from companies in surplus, from international sources, or from domestic developers of "offsets" that reduce emissions in other sectors.

7. The terms of the regulations can be varied by negotiated covenants between the government and industry. This provision would allow the flexibility needed to take into account concerns about competitiveness and early action. The flexibility provided by the covenant option would also mean that the regulations themselves could be kept short, simple and transparent. ${ }^{176}$

The legislation would recognize Kyoto Protocol emission units that can be used for international emissions trading, establish a Canadian emission unit to be used for domestic offset credits (under a system to be developed) and special units to implement the \$15 per tonne price guarantee that the federal government provided to industry. ${ }^{177}$ Regulations are

Ste online: Natural Resources Canada, Large Emitters Group <www.nrcan.ge.ca/lfeg-ggef/>. Natural Resources Canada, Discussion Paper, "Overview of Legislation" (November 2003), online Natural Resources Canada, Large I:mitters Group < www.nrcan.gc.ca/lieg-ggef/English/ol_en.pdis.

i". S.C. 1999, c. 33 [CEPA].

i" "Overview or Legislation," supra nole 173 at 1.

1i. thid at 1-2

i" sbid at 3 . 
envisioned to establish emission intensity-based targets for sectors and the formula for allocating permits to emitters. Provision would be made for covenants that could adjust sector emission intensity targets, compliance policy, quantification protocols, reporting requirements and compliance timing. ${ }^{178}$ This would provide flexibility to recognize credit for early action to reduce emissions, investment in relevant technology and to account for potential competitive distortions.

The scope of the legislation would be qualified by some form of de minimis emission threshold. ${ }^{179}$ However, authorization of international trades would be required to ensure that the level of international permits purchased by Canadian firms does not make it impossible to meet Canadian Kyoto Protocol emission reduction obligations.

\section{B. A Prelliminary Note on Federal JuRISDiction: Potentially Relevant Federal Powers}

This article does not analyze the constitutionality of federal GHG reduction legislation because there is not yet any federal legislation to analyze. Federal documents acknowledge that there will be a legal framework for the federal scheme, particularly "backstop" legally enforceable standards or requirements for the proposed large industrial emitter sectoral covenants and for the proposed offset credit trading system. ${ }^{180}$ This may mean making regulations under existing enabling provisions of $C E P A$ or enacting new legislation.

However, at this point, the question of federal jurisdiction can be addressed: (1) by identifying federal heads of power relevant to the general subject of GHG reduction using an emissions target, sectoral covenant/backstop and offsets trading approach; and (2) by considering the extent to which federal actions provide evidence that may support a particular characterization of whatever federal legislation ultimately emerges. In a general way this may be linked to federal enumerated heads of power and to the peace, order and good government power. A full constitutional analysis however must await enactment of legislation. From the federal perspective, this means that the legislation must be carefully designed and drafted to support characterization that will most likely lead to the conclusion that it comes within an enumerated head of federal jurisdiction or the peace, order and good government power.

Ibid. at 5: see also Natural Resources Canada, Discussion Paper, "Variation by Covenant" (January 2004), online: Natural Resources Canada, Large Emitter Group <www.nrcan.gc.ca/feg-gge//Fnglish/ var_covenant_en.pdßs.

174 "Overview of Legislation," supra note 173 at 2.

1*o) See Canada, Working Group on Offsets, Offet System Discussion Paper (Otawa: Environment Canada, 2003) at 2, online: Government of Canada, Climate Clange <www.climalechange.gc.ca/ English/publications/offset_dp/dp/dp_e.pdf $>$; Natural Resources Canada. Discussion Paper. "Discussion Paper on the Siructure and Issues of the Climate Cliange Covenants, Annex I: Draft Model Covenant" (July 2003) at 2-3, 9, online: Natural Resources Canada, Larger Emitters (iroup < www.nrcan .gc.ca/lfeg-ggef/English/disc2_en.pdis. 
Federal powers potentially relevant include s. 91(3), taxation, s. 91(2), criminal law, s. 91(27), regulation of trade and commerce and peace, order and good government (POGG).

\section{TAXATION}

Section 91(3) authorizes legislation to raise revenue by "any Mode or System of Taxation." 181 Apart from the immunity of provincial property from federal tax discussed above, there are few constitutional, as opposed to political, limitations on this federal power. Federal tax revenues can be spent on matters otherwise within provincial jurisdiction and this can be subject to terms and conditions. ${ }^{182}$

\section{Criminal LaW}

The Supreme Court of Canada in R. v. Hydro-Québec ${ }^{183}$ upheld provisions of CEPA that were essentially designed to assess and prohibit or regulate toxic substances and that included prohibitions on discharge of substances. But the Court split 5-4 and the minority argued very plausibly that though the toxics part of CEPA provided for regulation that included regulatory offences, it was not in substance criminal law. The majority acknowledged that a prohibition may be "so broad or all-encompassing" that it cannot be characterized as a matter of criminal law. ${ }^{184}$ Federal GHG reduction legislation is likely to include offences, for example, failure to comply with reporting and verification requirements and, most significantly, failure to comply with backstop standards by failing to file permits to cover actual GHG emissions.

The key question is whether these prohibitions are likely to be characterized as compliance elements of regulatory and covenant-based requirements of an offsets trading system, and not as fundamentally criminal prohibitions. According to the "Overview of Legislation" nonpaper, "[t]he foundation of the legislation will be a general prohibition with penalties in the case of non-compliance."185 This prohibition is described as "an emitter could not emit greenhouse gases (GHGs) without emissions permits equal to the level of its actual emissions." ${ }^{186}$ On its face, this prohibition seems to aim at a mere administrative matter filing sufficient permits. But the permits represent compliance with each emitter's emission limit, even though these limits will vary depending on whether emitters opt for quantitative reduction, basic permit purchase or purchase of offset or international credits. These individual emission limits are designed to meet national target limits that represent Kyoto commitments. The permit purchase aspect of the scheme may also be viewed as a form of exemption - a technique for design of prohibitions and offences endorsed by the Supreme Court in Hydro-Québec. ${ }^{197}$

Constitution, supra note 95.

See Winterhaven Stables, supra note 161. For another general analysis of relevant federal (and indeed provincial) powers sec Cluris Rolfe, Turning Down the Heat: Emissions Trading and Canadian implementation of the Kyoro Protocol (Vancouver: West Coast Environmental law Research Foundation, 1998) at especially e. 14, online: West Coast Environmental I.aw <www.wecl.ory' wcelpub/1998/12248.pdßs.

[1997] 3 S.C.R. 213.

thid. at 298.

"Overview of L.egislation," supra note 173 at 2.

Ibid.

Supra note 183. Sec also Firearms Reference, supra nole 121 at $794-95$ 
A more serious concern about criminal prohibition characterization is the extremely limited scope of the prohibition. It applies only to a small group of LFEs - the emissions of the large majority of smaller emitters being considered de minimis. Yet the LFE's contribution to the natural GHG emission total is undoubtedly significant. Focus on this small group may thus be a rational as well as an efficient technique for addressing this public concern. On the other hand, the $55 \mathrm{MT}$ LFE contribution to the $240 \mathrm{MT}$ overall target, with the remaining deductions to be addressed primarily through a variety of spending and voluntary techniques, suggests that the overall problem of GHG emission reduction is not in fact intended to be remedied through criminal prohibition.

\section{TRADE AND COMMERCE}

The difficulty with federal reliance on the trade and commerce power is that there is serious question of whether a legislative scheme that had its origin in Canadian GHG reduction commitments under the UNFCCC and Kyoto Protocol could, however the legislation is drafted, be characterized in substance as having commercial objectives and thus being in relation to regulation of trade and commerce. While offset credits or other tradeable emission rights may have commercial value and be traded like other commercial instruments, they are likely to be characterized as merely part of the overall scheme - instruments or mechanisms to achieve efficient GHG emission reduction. If that were the case, it would be unnecessary to address the "general regulation of trade and commerce" tests that have been developed by the Supreme Court of Canada. ${ }^{188}$

\section{PeAcli, ORder AND GoOd Government}

In order to come within the POGG power, a subject matter must be a matter of "urgent national concern" that is sufficiently distinct, single and indivisible to distinguish itself from matters of provincial concern, and must have a scale of impact on provincial jurisdiction that is consistent with the overall distribution of legislative power. ${ }^{189}$ Does global climate change and national GHG emission reduction meet these criteria? Climate change is a global and not merely a national problem. Its nature and urgency have been strongly supported, though not conclusively established, by scientific research. It is a problem that appears to require a precautionary approach. Thus the subject arguably has features of urgent national concern and can be defined in terms of its nature. But its scope is broad in view of the myriad sources of GHGs and its potential scale of impact on fundamental provincial jurisdiction over property and local undertakings, and potentially on Alberta's natural resource royalties and tax revenues, seems considerable.

"Provincial inability" - consequences of provincial failure to deal effectively with an interprovincial issue such as GHG emission reduction - is also relevant to whether the necessary distinctiveness or indivisibility exists. It does seem possible that provincial inaction or ineffectiveness could result in failure by Canada to meet its GHG reduction obligations under the Kyoto Protocol. However, the Supreme Court of Canada in Hydro-Qućbec sent a 
strong signal that it wished to reign in POGG jurisdiction by looking first at relevant enumerated federal powers and treating POGG as a true residual power. ${ }^{190}$

\section{CONSTITUTIONAL EVIDENCE}

Scientific evidence concerning the climate change phenomenon and the nature and course of international action would, as noted above, be part of any federal case to establish POGG jurisdiction. ${ }^{191}$ It may be highly relevant to both national concern and to distinctiveness and singleness, as it was in Crown Zellerbach. ${ }^{192}$

Other evidence that may be relevant is the course of federal-provincial communications and negotiations. For example, evidence of Alberta's "go it alone" approach, and reluctance or perhaps recalcitrance in the face of the federal climate change plan and proposals conceming such issues as national allocation of emission reduction requirements, a national approach to offsets, and apparent refusal to negotiate toward a Memorandum of Understanding (MOU) on these matters, may be considered evidence of provincial inability. On the other hand, this evidence is seriously undercut by continued federal delay in formulating specific proposals for implementation, including necessary legislation.

Government policy documents, particularly the federal and provincial climate change plans and supporting documents, would also be relevant. The non-papers mentioned above appear to emphasize prohibition as the basis of proposed federal legislation and do not adopt the language of national concern or provincial inability. But are the non-papers relevant? By their nature, they are discussion papers not intended to express federal policy.

\section{THE SignificanCE of POTENTIAL INCOMPatibILJTY}

Under the federal and Alberta Plans and Alberta Bill 37, various differences between the federal and Alberta schemes can be identified. Arguably, incompatibility can make it difficult or impossible for each scheme to achieve its objectives. Here are three examples:

\section{Scenario A:}

What if federal and provincial grant and incentive programs establish different entitlements and different benefits? Alberta factory owner A qualifies for provincial but not federal retrofit subsidies, while Alberta homeowner $B$ qualifies for both, to the chagrin of $A$ who complains that she pays federal tax too. 


\section{Scenario B:}

What if Alberta plant owners can, by means of covenant commitments and Alberta offset credits, comply with Alberta emissions intensity targets but still not be in compliance with federal emissions reduction requirements? The federal Plan, like the Alberta Bill, adopts an emissions intensity approach for large industrial emitters, but what if the federal reductions considered necessary to meet the $55 \mathrm{MT}$ federal reduction target for LFEs result in more expensive requirements than those of Alberta? This could occur if the Alberta scheme counts credits resulting from certain early action measures or offsets that the federal scheme does not, or if federal intensity targets are more onerous than those established by the province.

\section{Scenario C:}

What if Alberta plants faced federal legislation that adopted emission targets and an approach based on real quantified GHG reductions while Alberta maintained its emissions intensity approach? Though this scenario is entirely hypothetical given federal endorsement in the Climate Change Plan for Canada of an emissions intensitybased scheme for large final emitters, it is worth considering because it provides additional perspectives on scenario $B$.

What does constitutional law say about such potential incompatibility? Lets us examine the scenarios.

\section{Scenario A:}

Factory owner A may remain unhappy but would have no constitutional remedy. Both levels of government have taxation powers. The federal power is plenary: "The raising of revenue by any mode or system of taxation." ${ }^{193}$ It can thus tax nationally and can spend the revenue as it pleases. In constitutional terms, this latter is the federal "spending power" which has been held to include attaching terms and conditions to grants and expenditures. ${ }^{194}$

No doubt, compatible spending programs and cost-shared programs would be desirable, but rationality and efficiency are not constitutionally mandated. However, proposed federal spending in provincial fields may, as a tactical matter, provide incentives for a province keen on managing its own natural resources and industrial strategies to either develop its own programs or negotiate shared cost arrangements with the federal government. 


\section{Scenario B:}

The Alberta plant owners would be in the position of being in compliance with Alberta GHG requirements, but not with federal requirements, unless of course they invested in sufficient federal emission credits. Assuming that both the provincial legislation and the as-yet-unenacted federal legislation are otherwise constitutionally valid according to the division of powers analysis outlined above, what is the effect of this inconsistency in relation to the Alberta plant owners?

Under the doctrine of "paramountcy," federal legislation will prevail over the provincial where the requirements of the two statutes are in conflict. Courts have required that this conflict go beyond mere inconsistency and amount to "conflict in operation," 193 so that compliance by affected persons with the requirements of one law places them in breach of requirements of the other. This is not our scenario. The Alberta plant owners can, by investing in process or technology changes or in additional federal emission permits, domestic offset credits, international permits or a combination of all three, comply with both federal and provincial requirements. Alberta's Bill 37 does not make Alberta emission targets the only targets in force in the province.

Evidence of inconsistency (whether in the form of operational conflict or simply inconsistency as more generally understood) may also be relevant to federal claims to legislative jurisdiction based on the peace, order and good government power and provincial inability to effectively address the problem of GHG emission reduction. Such evidence of provincial inability might be strengthened if federal permit requirements were based on (or include among other types of permits) Kyoto units that are linked directly to Canada's assigned amount units for the five years of the first commitment period under the Kyoto Protocol. This might strengthen the federal case if the provincial government were unable to show any clear nexus between its own target and Kyoto obligations.

\section{Scenario C:}

The paramountcy analysis here is the same as for scenario $B$. There would still be no necessary operalional conflict between Alberta's emission intensity targets, with sectoral covenant and firm-based backstop regulatory requirements and offset trading options, and a hypothetical federal scheme based on overall and emitter-specific targets that reflected real GHG emission reductions. Affected Alberta plant owners could still comply with both sets of requirements even if this meant using different permits to meet emission requirements for provincial and federal purposes. In this scenario, there would be a fundamentally greater difference between the legislation than in scenario $B$ because the federal requirements would be more closely linked to real emission reduction and consequential environmental quality improvement. Intensity-based requirements, by their nature, factor in a significant element of jurisdictional and firm- 
based economic performance. That, depending on GDP growth and the rate of technological innovation, may actually result in increased real GHG emissions. This difference may be sufficient to show that it is not merely a matter of complying with more and less stringent environmental standards, but of complying with standards that are fundamentally different - the provincial standard based on economic efficiency and the federal based on environmental protection and improvement.

\section{Potential Equivalency or Incorporation by Reference}

There are a variety of federal-provincial cooperation techniques that could be used by the Alberta and federal governments to integrate GHG emissions management legislation. One is an interjurisdictional agreement delegating to one government the authority to administer a statutory regime of another government. Section 9 of $C E P A$ makes provision for this kind of delegation. This approach has been long used to support administration and enforcement of the federal Fisheries $A c t^{196}$ by some provinces. Administrative agreements can delegate only administrative functions and not the power to legislate. The Supreme Court of Canada has made it clear that explicit delegation of power to legislate by one level of government to another, where to do so would alter the distribution of legislative power, is constitutionally impermissible. ${ }^{197}$

At a broader policy level, federal-provincial MOUs, including multi-jurisdictional MOUs involving the federal government and most provinces, have been used. An example is the 1998 Canada-wide Accord on Environmental Harmonization. ${ }^{198}$ These are usually focused on objectives and are thus too vague and general to have legal force. Consequently, they are not directly enforceable by the governments or by corporations and citizens.

Another set of cooperative instruments does have legal force because both authority to make agreements and specific criteria are included in federal and provincial statutes. One variety is equivalency agreements, a technique established by the $C E P A$. Section 10 of $C E P A$ states that its provisions do not apply in any province for which there is an order declaring that the provisions do not apply. Such orders may be made by the federal cabinet on the recommendation of the Minister of the Environment, where the federal environment minister and a provincial or territorial minister agree in writing that the province or territory has equivalent laws in force. This is stated to mean laws that are equivalent to regulations made under specified $C E P A$ regulation-making powers and that include provisions for citizen requests for investigations of alleged offences are similar to those in CEPA. The Alberta Equivalency Order of December 1994, declared laws to be equivalent to a series of specified $C E P A$ regulations. ${ }^{199}$ These CEPA regulations were thus "withdrawn" from application in Alberta.

R.S.C. 1985, c. F-14

Nova Scotia (A.G.) v. Canada (A.G.). [1951] S.C.R. 31. It is possible for one governinent to agree to extend the application of an otherwise valid law: Dick v. R., [1985] 2 S.C.R. 309 [Dick]: R. v. Morris (2004), 237 D.L.R. (4th) 693 (B.C.C.A.).

Online: Canadian Council of Ministers of the Environment (CCML) <wuw.ccme.ca/initiatives/ environment.html?category_id $=25>$.

Alberta Equivalency Order, SOR94-752. 
A related statutory technique for interjurisdictional program integration is express incorporation by reference in the legislation of one jurisdiction of specific legislative provisions of another. The Supreme Court of Canada has held that even future statutory changes made by the other jurisdiction can be validly incorporated by reference in legislation. ${ }^{200}$

The constitutional prohibition on interdelegation of legislative power has been solved in an analogous way by federal and provincial "mirror" legislation. Such legislation establishes the same institutions by utilizing both federal and provincial legislative powers and gives these boards or tribunals the same powers and standards to the extent of both federal and provincial legislative jurisdiction. ${ }^{201}$ An example is the legislation that establishes and empowers the Atlantic region offshore petroleum boards. ${ }^{202}$ It is unlikely that this technique is relevant to GHG emission reduction since the objective is to facilitate trading as a method of achieving efficient emission reduction rather than establishing a regulatory agency to attempt to achieve that objective by regulatory means.

How might these federal-provincial cooperative techniques be used in relation to GHG emission reduction schemes? Administration and enforcement agreements may be a future step, but administrative arrangements first require a government to accept the legislative jurisdiction and the emission targets and mechanisms embodied in the legislation of the other govermment. It is also clear that more than mere MOU negotiation is required, though this may be a first step. Something weightier, more specific and legally enforceable, or at least carrying considerable intergovernmental relations weight, is required.

$C E P A$ 's equivalency provisions specifically contemplate recognition of provincial laws as equivalent to federal international air pollution regulations under s. 167. It is likely that the latter does provide legal authority for federal regulations concerning GHG emissions, and in combination with s. 327 of CEPA, which authorizes regulations for "systems relating to tradeable units," could serve as the legal basis for a comprehensive GHG emissions trading regime.

But such an equivalency arrangement is several steps from reality. First, the governments would have to agree that the $C E P A$ equivalency mechanism is appropriate. As a second step, they would have to agree on GHG emission targets and what should be counted toward meeting targets as well as the essential elements of a trading system. This would have to be promulgated as a federal regulation and then as an agreement made that the Alberta provisions are equivalent to those of the federal regulation. Finally, the federal cabinet would have to issue an equivalency order, perhaps amending the existing Alberta Equivalency Order.

A problem with the original $C E P A$ equivalency scheme is that there has never been agreement on the appropriate test for equivalency of standards, particularly whether it means 
equivalency of results. This problem mirrors the debate about how Alberta and federal targets compare - particularly what counts toward meeting targets.

\section{Conclusions}

Alberta's Climate Change and Emissions Management Act (Bill 37) provides the legal framework for implementing Alberta's Strategy for Action on Climate Change. It establishes targets for reduction of GHG emissions from provincial sources, sets out the parameters for voluntary sectoral agreements for emissions reduction and, in a rather oblique manner, creates the basis for an emission offset trading system. The scheme is not explicitly designed to address Canada's Kyoto Protocol target obligations. It is premised not on quantified emission reductions but on emissions intensity; and it aims at 2020, not the 2008-2012 Kyoto Protocol commitment period.

Federalism analysis shows a strong likelihood that the Bill is constitutionally valid. Its pith and substance or leading feature is reduction of GHG emissions from Alberta sources though in a broader federal-provincial relations sense, its context is an interjurisdictional equity issue that recalls the energy wars of the late 1970s and early 1980s. This subject matter fits comfortably under the exclusive provincial power in relation to property and civil rights in the province, but may also draw assistance from the local works and undertakings head and the residual, matters of local and private nature head.

We have shown that, notwithstanding the Bill's provision that sink rights are property rights and government rhetoric concerning enhancement of provincial ownership and control of natural resources, the Bill does not expand provincial ownership claims. There is no vesting of sink rights in the province and, in any event, provincial ownership that might have been a basis for immunity from application of a federal taxation law is lost when resource ownership passes to private resource producers under Alberta's natural resource allocation and production regime. In sum, while Bill 37 is likely valid, it does little if anything to protect Alberta, or emitters carrying out operations in Alberta, from the application of a federally enacted Kyoto compliance scheme (assuming that such a scheme would itself pass constitutional muster).

Analysis of federal jurisdiction to implement Canada's climate change plan is premature. Details of the federal plan are still under development. In any event, while potential heads of federal jurisdiction, particularly criminal law, peace, order and good government (national concem) and possibly trade and commerce, can be identified, analysis must be based on specific legislative provisions.

It is nevertheless possible that Bill 37 could ultimately be rendered constitutionally inoperative as a result of federal GHG emissions reduction legislation being judicially upheld and being found to be in operational conflict with the valid provincial legislation. However, current federal proposals suggest that this is not likely. Conflict, in the sense of compliance with one law placing affected persons in breach of the other, is unlikely. If federal and provincial statutes establish different emission limits or targets, there is no conflict because affected persons can comply with both by meeting the more stringent requirement. 
Legislative approaches and mechanisms for coordination of federal and provincial legislation, with each staying within its sphere of constitutional jurisdiction, are available. These include the incorporation by reference by each government of statutory provisions of the other, assuming that the agreed result is a coherent and coordinated scheme. Another possibility is utilizing the equivalency mechanism in CEPA. This too hinges on agreement concerning targets and key elements of a trading scheme and on ways of meeting targets that can be considered plausibly to be equivalent. These could then be expressed in a federal regulation that would become the benchmark for an equivalency agreement with Alberta. 